\title{
Geochronology of Hemphillian-Blancan Aged Strata, Guanajuato, Mexico, and Implications for Timing of the Great American Biotic Interchange
}

\author{
Bart J. Kowallis \\ bkowallis@byu.edu \\ John J. Flynn \\ Clarita Nunez \\ Oscar Carranza-Castaneda \\ Wade E. Miller \\ See next page for additional authors \\ Follow this and additional works at: https://scholarsarchive.byu.edu/facpub \\ Part of the Geology Commons
}

\section{Original Publication Citation}

The Journal of Geology 113.3(May 25): 287-37.

\section{BYU ScholarsArchive Citation}

Kowallis, Bart J.; Flynn, John J.; Nunez, Clarita; Carranza-Castaneda, Oscar; Miller, Wade E.; Swisher, Carl C. III; and Lindsay, Everett, "Geochronology of Hemphillian-Blancan Aged Strata, Guanajuato, Mexico, and Implications for Timing of the Great American Biotic Interchange" (2005). Faculty Publications. 382. https://scholarsarchive.byu.edu/facpub/382 accepted for inclusion in Faculty Publications by an authorized administrator of BYU ScholarsArchive. For more information, please contact ellen_amatangelo@byu.edu. 


\section{Authors}

Bart J. Kowallis, John J. Flynn, Clarita Nunez, Oscar Carranza-Castaneda, Wade E. Miller, Carl C. Swisher III, and Everett Lindsay 


\title{
Geochronology of Hemphillian-Blancan Aged Strata, Guanajuato, Mexico, and Implications for Timing of the Great American Biotic Interchange
}

\author{
John J. Flynn, ${ }^{1}$ Bart J. Kowallis, ${ }^{2}$ Clarita Nuñez, Oscar Carranza-Castañeda, ${ }^{3}$ \\ Wade E. Miller, ${ }^{2}$ Carl C. Swisher III, ${ }^{4}$ and Everett Lindsay ${ }^{5}$ \\ Department of Geology, Field Museum, Chicago, Illinois 60605, U.S.A. \\ (e-mail: jflynn@amnh.org)
}

\begin{abstract}
A B S T R A C T
We present new geochronologic (magnetostratigraphy, fission-track and ${ }^{40} \mathrm{Ar} /{ }^{39} \mathrm{Ar}$ radioisotopic dates, biostratigraphy) data constraining the age of three separate sequences and a composite section from Guanajuato, Mexico. Those data make this one of the most complete and precisely age-calibrated sequences in North America spanning the Hemphillian/Blancan North American Land Mammal "Age" (NALMA) boundary interval, and the data further constrain the timing and pattern of the Great American Biotic Interchange (GABI). In total, 196 samples (77 sites) were used to construct the magnetic polarity stratigraphies, with eight fission-track analyses and four new ${ }^{40} \mathrm{Ar} /{ }^{39} \mathrm{Ar}$ radioisotopic dates. The sections sampled are possibly latest Miocene to Late Pliocene in age, spanning about $2.7 \mathrm{~m}$.yr. $(\sim 5.5-2.7$ $\mathrm{Ma}$ ), from Chrons C3n.4n or C3r to C2An.1n. The radioisotopic dates and magnetostratigraphic correlations indicate the Hemphillian/Blancan NALMA boundary at Guanajuato in central Mexico is 4.7-4.8 Ma, and it probably lies within Chron C3n.2r, consistent with most prior age estimates and correlations. Our analyses indicate that a variety of "invaders" (taxa with South American ancestry, including Megalonyx, Glossotherium, and Plaina) clearly were present by at least 4.7-4.8 Ma and therefore much earlier in lower latitude Middle America than in more temperate parts of North America. Others (e.g., Neochoerus, Glyptotherium) were present shortly thereafter but still much earlier than in higher latitudes. Thus, the first appearances of these five immigrant taxa can no longer be used to define the beginning of the late Blancan. This timing significantly predates the earliest documented major influxes of North American forms into South America, is at least 1.5-2 m.yr. earlier than the beginning of the GABI previously recorded in North America (beginning of the Blancan [Bl 2], 2.7 Ma), and suggests faunal provinciality and more staggered arrival and dispersal of South American immigrants than indicated in temperate sequences.
\end{abstract}

Online enhancements: tables, figures.

\section{Introduction}

Late Cenozoic mammal faunas from the northeastern part of the state of Guanajuato in cen2004

Manuscript received June 23, 2004; accepted December 20,

${ }^{1}$ Author for correspondence; present address: Division of $\mathrm{Pa}$ leontology, American Museum of Natural History, Central Park West at 79th Street, New York, New York 10024, U.S.A.

${ }^{2}$ Department of Geology, Brigham Young University, Provo, Utah 84602, U.S.A.

${ }^{3}$ Departamento de Geología, Universidad Nacional Autónoma de México, Juriquilla, México.

${ }^{4}$ Berkeley GeoChronology Center, Berkeley, California 94709, U.S.A.; present address: Department of Geological Sciences, Rutgers University, Piscataway, New Jersey 08854, U.S.A.

${ }^{5}$ Department of Geosciences, University of Arizona, Tucson, Arizona 85721 U.S.A. tral Mexico have been collected and studied for $>25$ yr (e.g., Carranza-Castañeda and FerrusquíaVillafranca 1978; Carranza-Castañeda and Miller 1980, 1988, 1996, 1998, 2000, forthcoming; Dalquest and Mooser 1980; Carranza-Castañeda et al. 1981, 1994, 2000; Ferrusquía-Villafranca and Carranza-Castañeda 1981; Montellano-Ballesteros and Carranza-Castañeda 1981; Miller and Carranza-Castañeda 1984, 1998, 2001; Carranza-Castañeda 1989, 1991, 1992). Mammal-bearing sequences in this area range from middle Hemphillian through Irvingtonian North American Land Mammal "Ages" (NALMAs), or Late MiocenePleistocene epochs, with most of the fossiliferous 
sequences being late Hemphillian-Blancan in age. Woodburne and Swisher (1995, p. 351) noted that "Stratigraphic successions that span the Hemphillian/Blancan boundary are rare in North America." Although there are a number of individual sequences of either late Hemphillian or early Blancan age, few are documented to lie between 5 and $3 \mathrm{Ma}$, and virtually none span that entire interval, leading to continuing controversy about the precise age of the boundary (estimates range from 4.0 to $5.0 \mathrm{Ma}$ and Chron C3n2n-C3n4n; Lindsay et al. 1975, 1984, 2002; Lundelius et al. 1987; Repenning 1987; Woodburne and Swisher 1995; Albright 1999). The sequence in Guanajuato, therefore, represents one of the most continuous sedimentary packets across the Hemphillian/Blancan NALMA boundary in North America (Carranza-Castañeda and Miller 1996) and may help refine age estimates and test synchrony for that boundary and associated biochronologic events in various parts of the continent. Currently available geochronologic data from Guanajuato include preliminary biostratigraphies and faunal lists for many sections and several radioisotopic dates; no paleomagnetic data have been reported previously to permit correlation to U.S. sequences. The authors are undertaking complementary work on other lower latitude sequences (Tecolotlán basin, Jalisco, Mexico).

We therefore undertook intensive field and laboratory paleomagnetic and radioisotopic analyses from 1986-1987 and 1995-2000 to more precisely correlate and constrain the ages of the upper Hemphillian to Blancan NALMA sections. This temporal interval is critically important for resolving events surrounding the Great American Biotic Interchange (GABI; Patterson and Pascual 1972; Stehli and Webb 1985; Jackson et al. 1996). It is clear that a few "waifs" or "heralds" had dispersed both northward (two genera of ground sloths) and southward (procyonids) by the Late Miocene (at least 8-9 Ma; Webb 1985, 1997; Campbell et al. [2001] also have recently reported a Late Miocene age for gomphotheriids from the Amazon of SE Perú). Yet the vast majority of the diverse "legions" of dispersing taxa did not appear in the fossil record until much later (i.e., $2.5 \mathrm{Ma}$ in North America, late Blancan NALMA [ 2-2.8 Ma, oldest occurrences for Glossotherium, Neochoerus, and Glyptotherium], Webb 1985; and 2.5-3.0 Ma in South America, beginning of the Uquian South American Land Mammal "Age" [SALMA], Flynn and Swisher 1995). However, crucially important strata from intervals immediately preceding the documented first occurrences of "legions" have been poorly sampled or poorly constrained in age in both North Amer- ica (late Hemphillian-early Blancan NALMA) and South America (a likely pre-Uquian, postChapadmalalan SALMA hiatus, compounded by few geochronologic constraints on these bracketing SALMAs). Central Mexico represents the southernmost part of North America that preserves extensive, fossiliferous Late Tertiary deposits. In addition, the Guanajuato strata, lying between the Sierra Madre Oriental and Sierra Madre Occidental ranges, sample a crucial likely migratory pathway ("geographic funnel") for the earliest GABI immigrants and emigrants, and they already have yielded both immigrants from South America ("a marsupial, several edentates, and at least one giant rodent [a capybara]") and North American emigrants ("including horses, camels, and a variety of carnivores and rodents"; Carranza-Castañeda et al. 1994, p. 2). Thus, fossiliferous upper Hemphillian-lower Blancan strata at Guanajuato, with dateable volcanic ashes and sediments amenable to paleomagnetic analyses, provide an unparalleled opportunity to constrain the timing and pattern of biotic changes during the main GABI dispersals.

We present geochronologic conclusions made on the basis of six new fission-track (five from Guanajuato, one from Hidalgo) and four new singlecrystal laser-fusion ${ }^{40} \mathrm{Ar} /{ }^{39} \mathrm{Ar}$ radioisotopic dates (two from Guanajuato, one each from Hidalgo and Jalisco) and paleomagnetic analyses of almost 200 samples from $>75$ sites in three extensive or composite stratigraphic sections spanning the latest Hemphillian-early Blancan NALMAs (figs. 1-6; tables 2-4; supplementary data [figs. 7-11; tables 57 in the online edition of the Journal of Geology and also available from the Data Depository in the Journal of Geology office upon request]). Available biostratigraphic data enabled us to locate, with varying degrees of precision, the position of the Hemphillian/Blancan NALMA boundary in all the Guanajuato sections (except the extremely short Arroyo Belén section, which is entirely Blancan). The sediments sampled in this study all are considered part of the informal lithostratigraphic unit known as the "Ranch Viejo Beds" (Carranza-Castañeda and Miller [1996], who inadvertently referred to them as the "San Miguel Allende Beds," incorrectly citing an article by Carranza-Castañeda et al. [1994] that applied the name "San Miguel Allende Beds" to Cretaceous strata underlying Oligo-Miocene volcanics and the Mio-Pleistocene "Rancho Viejo Beds"]), with a maximum composite thickness of $\sim 100 \mathrm{~m}$. The sedimentary and volcaniclastic Rancho Viejo Beds are green to gray to white, weakly indurated, friable, clays and silty to sandy clays, with variable sand, gravel, and tuffa- 
Table 1. Abbreviations

\begin{tabular}{ll}
\hline Term & \multicolumn{1}{c}{ Definition } \\
\hline NALMA, SALMA & $\begin{array}{c}\text { North American and South American Land Mammal "Age" (not a formal } \\
\text { geochronologic age and hence informally termed biochronologic "age"; } \\
\text { the quotation marks are implicit in NALMA and SALMA throughout) } \\
\text { Blancan NALMA }\end{array}$ \\
B1 & $\begin{array}{l}\text { First (stratigraphic) appearance } \\
\text { FA }\end{array}$ \\
GABI & Global magnetic polarity timescale \\
GMPTS & Guanajuato stratigraphic section \\
GTO & Guanajuato paleomagnetic sampling site \\
GUA & 40 Argon/39argon radioisotope ratio \\
${ }^{40}$ Ar/ ${ }^{39}$ Ar (also Ar/Ar) & Fission track \\
FT & Alternating field \\
AF & Maximum angular deviations, in least squares fit analyses \\
MAD & Angular radius of the cone of confidence ( $\alpha$ ) about the observed mean \\
$\alpha_{95}$ & Fisher precision parameter \\
$\kappa$ & J.J.F., Flynn; B.J.K., Kowallis; C.N., Nuñez; O.C., Carranza-Castañeda; W.E.M., \\
Author initials & Miller; C.C.S., Swisher; E.L., Lindsay \\
&
\end{tabular}

ceous components. They probably were deposited as point bar sequences in a meandering river channel and as adjacent floodplain deposits (CarranzaCastañeda et al. 1994). The strata are horizontal, making tectonic tilt corrections unnecessary, and unconformably overlie a sequence of OligoceneMiocene andesites.

\section{Radioisotopic Dating and Ash Geochemistry Correlations}

Before this project there were only two preliminary radioisotopic dates from these sequences /reported without analytical information or error bars: 4.6 Ma, from the Rancho El Ocote section [Kowallis et al. 1986]; 3.6 Ma, from the Arrastracaballos locality [volcanic ash GTO-6, Ranch Viejo section], as reported by C.C.S. in an article by Carranza-Castañeda [1991]; Carranza-Castañeda and Miller 1996). These preliminary results have not been substantiated by further analyses of the samples, and we will not consider them further. Preliminary work on this project yielded 10 new dates from the Guanajuato and nearby sequences (Kowallis et al. 1998), indicating an age of approximately $4.8 \mathrm{Ma}$ for the Hemphillian/ Blancan NALMA boundary in central Mexico.

In this article, we provide the first detailed analytical data and slightly revised age determinations for four ${ }^{40} \mathrm{Ar} /{ }^{39} \mathrm{Ar}$ dates on sanidines and nine fission-track dates on zircons (fig. 1 [FT]; table 2 [Ar/Ar and FT]; supplementary data [figs. 7-11; tables 5-7; Ar/Ar and FT]). Two of the ${ }^{40} \mathrm{Ar} /{ }^{39} \mathrm{Ar}$ and six of the FT dates are from the Guanajuato sections, and the remaining two are new dates from other strata of similar age in the region. Sanidine single-crystal, laser-fusion ${ }^{40} \mathrm{Ar} /{ }^{39} \mathrm{Ar}$ analyses were performed at the Berkeley Geochronology Center by C.C.S. (following experimental and analytical techniques of Kowallis et al. [1995] and Flynn et al. [1997]), and external-detector FT analyses of zircons were performed by B.J.K. at Brigham Young University (following techniques in work by Kowallis et al. [1986, 1998]).

Electron microprobe analyses of glass from 14 locations and at least six stratigraphic levels all gave rhyolitic compositions, consistent with their phenocryst mineralogy of sanidine, quartz, and plagioclase (Adams 2001). Hornblende is the most common mafic phase, occurring in about half of the ash beds, while biotite and pyroxene are less common. Apatite and zircon are usually present as accessory phases. Geochemical fingerprinting of glass from the ash beds within the HemphillianBlancan strata (Adams 2001) indicates correlations between GTO-2C/GTO-43/GTO-5D, GTO-11/ GTO-5A, and GTO-5B/GTO-6/GTO-12B. Three ashes, two at Arroyo El Tanque and one, GTO-12A, in La Pantera II, appear to be unique and do not correlate with ashes in any other section. These geochemical correlations between different sections are generally consistent with other lithostratigraphic indicators, paleomagnetic correlations, and radioisotopic dates, with the following exceptions: GTO-5B and GTO-6 are indistinguishable chemically but may fall within different polarity zones (although the GTO-6 polarity is ambiguous), and GTO-2C and GTO-43 also correlate geochemically and lie in normal polarity zones that might be correlated to different magnetochrons. It is possible that these are chemically similar but different ash beds. 

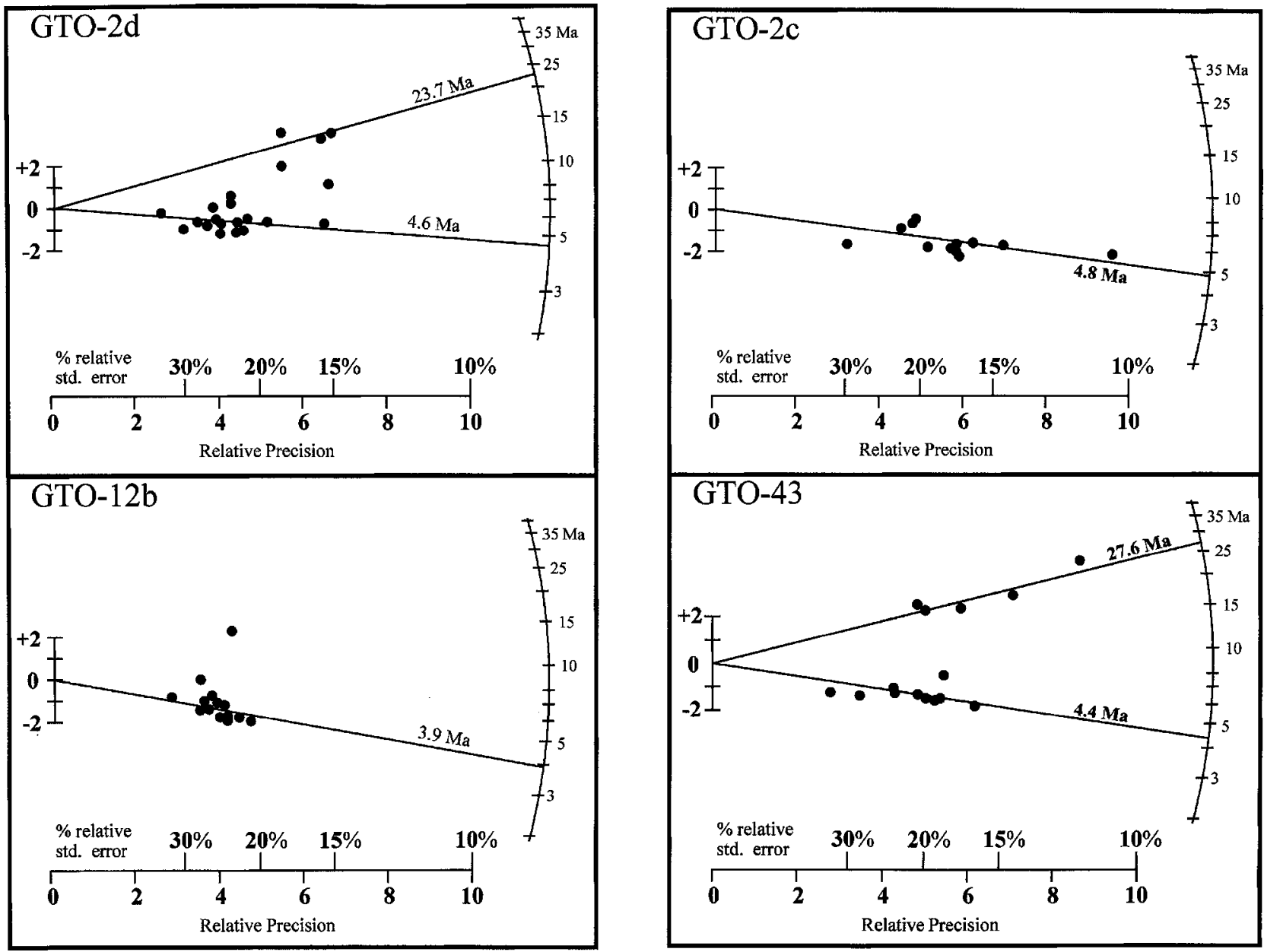

Figure 1. Fission-track dates (radial plots, following Galbraith 1988, 1990) from Guanajuato. For additional sample plots, see supplementary data (figs. 7-11; tables 5-7 in the online edition of the Journal of Geology and also available from the Data Depository in the Journal of Geology office upon request).

Detailed radioisotopic dating analyses include "peak" as well as "mean" ages for the FT dates, present evidence for the ages of detrital contaminant grains in both the FT and Ar/Ar samples, and slightly modify age determinations and associated errors presented previously for several Blancan horizons (Kowallis et al. 1998; GTO-5A, GTO-2D, HGO-12C). In addition, the preliminary $4.1 \pm 0.5-$ Ma FT date (GTO-11, Blancan horizons, California Mountain, near the Rancho Viejo property; Kowallis et al. 1998) is probably not reliable because it now appears to be a complex mix of at least three populations of detrital grains (peak ages: 4.6, 6.9, $20.7 \mathrm{Ma}$; fig. 8). Detrital grains with ages of 4.5-8.7 $\mathrm{Ma}$ (e.g., GTO-5A, Ar/Ar) and 20-30 Ma (Ar/Ar and FT, many samples) are consistent with periods of regional silicic volcanism and later erosion and re- working into Hemphillian-Blancan strata of this area (Kowallis et al. 1998).

The new radioisotopic dates provide more precise chronologic control on the ages of the various Guanajuato sequences and important independent constraints for correlation of several of the magnetostratigraphies to the GMPTS. Three dates /two FT, one Ar/Ar from Jalisco) associated with Hemphillian faunas range from 4.4 to $4.89 \mathrm{Ma}$, while seven dates (four FT, three Ar/Ar) in Blancan levels range from 3.32 to $4.70 \mathrm{Ma}$, suggesting an age of $\sim 4.7$ to $4.9 \mathrm{Ma}$ for the boundary at Guanajuato. This range and distribution of $\mathrm{FT}$ and ${ }^{40} \mathrm{Ar} /{ }^{39} \mathrm{Ar}$ dates (table 2) bracketing the Hemphillian/Blancan NALMA boundary in these sections is generally consistent with both prior estimates of the age of that boundary (but possibly slightly younger than 
Table 2. Radioisotopic Dating: ${ }^{40} \mathrm{Ar} /{ }^{39} \mathrm{Ar}$ and Fission-Track Analyses

\begin{tabular}{lc}
\hline Sample & Date \\
\hline${ }^{40} \mathrm{Ar} /{ }^{39} \mathrm{Ar}$ sample (lab no.; $n=$ grains averaged): & Weighted mean age $(\mathrm{Ma}) \pm$ SE $(\mathrm{mean} \pm$ SD [SEM]): \\
GTO.2D (\#50436; $n=12)$ & $4.747 \pm .032(4.736 \pm .141[ \pm .041])$ \\
GTO.5A (\#50430; $n=8)$ & $3.361 \pm .1(3.357 \pm .044[ \pm .016])$ \\
HGO.12C (\#50432; $n=11)$ & $4.591 \pm .007(4.593 \pm .011[ \pm .003])$ \\
TECO.20 (\#50433; $n=1)$ & $4.938 \pm .160$ \\
Fission-track sample no. (grains averaged): & Weighted mean age (Ma) $\pm 1 \sigma$ SE (youngest age populations): \\
GTO.2A (5 youngest grains) & $5.7 \pm .4$ \\
GTO.2C (all 12 grains) & $4.8 \pm .2$ \\
GTO.2D (15 youngest grains) & $4.6 \pm .3$ \\
GTO.5B (no mean calculated) & $\ldots$ \\
GTO.11 (no mean calculated) & $\ldots . .3$ \\
GTO.12B (12 youngest grains) & $3.9 \pm .3$ \\
GTO.43 (9 youngest grains) & $4.4 \pm .3$ \\
GTO.55 (3 youngest grains) & $3.8 \pm .5$ \\
HGO.12C (6 youngest grains) & $4.2 \pm .3$ \\
\hline
\end{tabular}

Note. For analytical details, including full data tables, standards, and irradiation parameters, see supplementary data (figs. 7-11; tables 5-7 in the online edition of the Journal of Geology and also available from the Data Depository in the Journal of Geology office upon request).

that favored by Lindsay et al. 2002) and the preferred correlations for the longer temporal scope of the Guanajuato strata relative to other known North American sequences.

\section{Paleomagnetic Results}

Paleomagnetic samples were collected (E.L., assisted by W.E.M., O.C., C.C.S.) from measured stratigraphic sections in three sequences (figs. 3-6). All paleomagnetic analyses were performed in the Field Museum's magnetically shielded Paleomagnetics Laboratory (C.N. and J.J.F.); equipment and analytical methods follow the work of Flynn et al. (1989, 1997; see also supplementary data [figs. 711; tables 5-7]). Magnetic polarity stratigraphies used only Class I reliability sites, with supplementary information from Class II-III sites (using statistical tests of Watson [1956a, 1956b] and reliability classification [I-V in descending reliability] modified from the work of Opdyke et al. [1977]; see Flynn et al. 1989, 1997). Pilot paleomagnetic analyses of the Guanajuato specimens were done in two batches following two seasons of field collecting (figs. 2, 9). In the first batch (GUA-001-031, collected in 1987), 10 specimens were chosen from the spectrum of lithologies of 31 sites for pilot blanket demagnetization studies and were subjected to 20 steps of combined AF (5-100 mt) and subsequent thermal $\left(200^{\circ}-650^{\circ} \mathrm{C}\right)$ demagnetization. Of these 10 pilot samples, one was found unstable, four gave ideal Zijderveld vector demagnetization plots (two normal, two reversed), and the remaining five gave acceptable results. Most sites responded best to the AF treatment alone; this method gave a more linear stable decay of magnetization to the origin, so the remaining specimens from these sections were treated with only three to four steps of AF demagnetization. The number of pilot samples was increased in the second batch $(35$ specimens collected in 1995; GUA-101-156) to better understand their magnetic characteristics because a few of the initial samples were unstable or gave ambiguous results even when treated with combined progressive AF (5 to 50,60 , or $70 \mathrm{mt})$ and thermal $\left(200^{\circ}, 400^{\circ}, 500^{\circ}\right.$, $600^{\circ}, 650^{\circ} \mathrm{C}$ ) methods of demagnetization. On the basis of these extended analyses, remaining specimens were treated similarly to those in the earlier batch, with three to 12 steps of AF demagnetization only.

The low coercivity and the maximum $580^{\circ} \mathrm{C}$ blocking temperature of most characteristic magnetizations isolated during thermal and AF demagnetization of pilot samples (representing more than half [45/77] of all sites) suggest that the dominant magnetic remanence carrier in most samples is magnetite or titanomagnetite, with only minor contributions from goethite or hematite (presumably secondary mineralizations). This is consistent with the general lithologic characteristics of the generally pale gray, tuffaceous silts to fine sandstones.

In total, 196 samples from 77 sites were used to construct the magnetic polarity stratigraphies (figs. $3-6,10,11$; tables $3,4,7)$. Samples from an additional 10 sites yielded soft, fragile, and poorly consolidated specimens that did not survive transport or sample preparation. Using a stringent criterion of eliminating specimens with MAD $>15^{\circ}$ for characteristic magnetizations (Butler 1992), the individual specimen data were then averaged (Fisher 


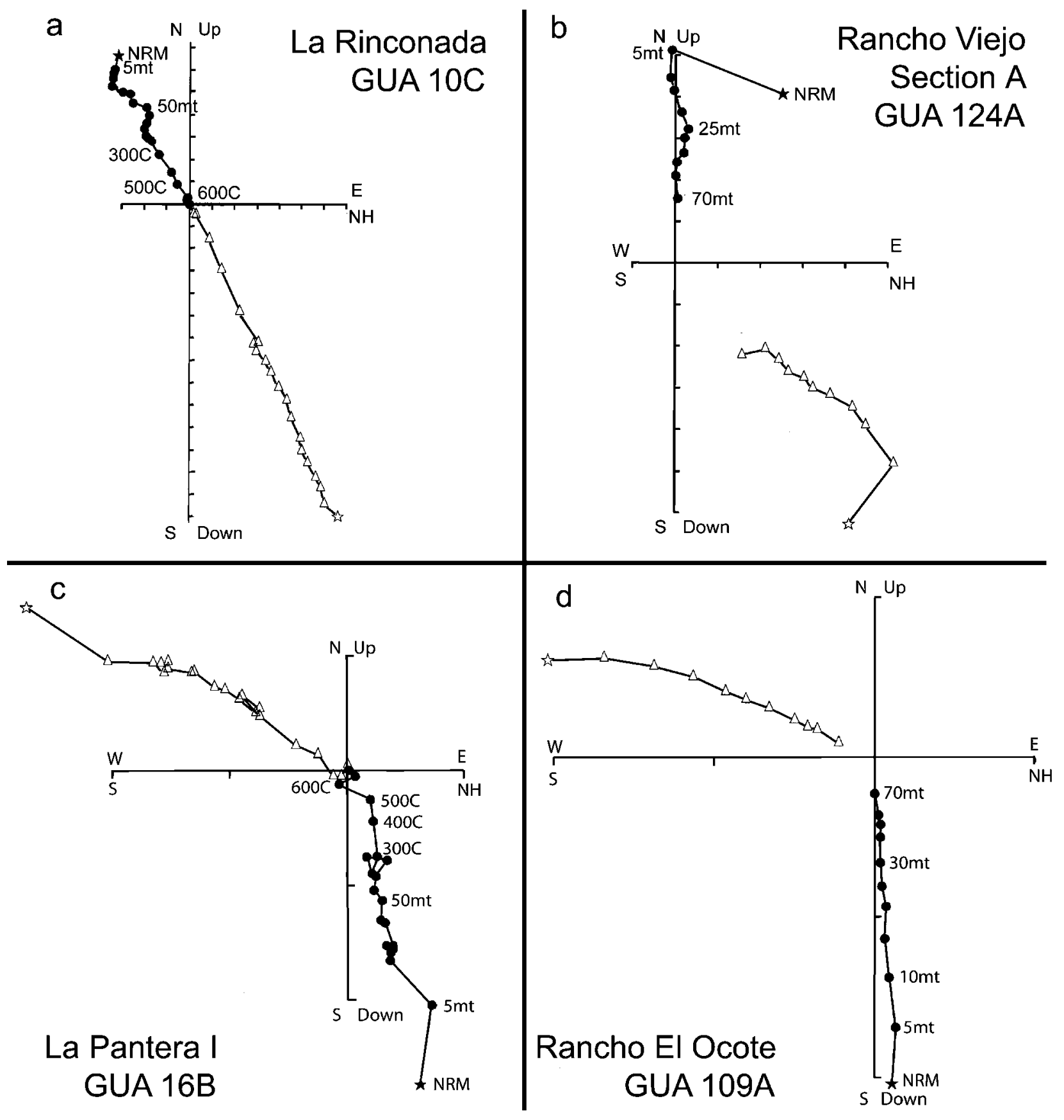

Figure 2. Representative vector demagnetization plots. Orthogonal projections $(a-d)$ of alternating field (AF) and/ or thermal demagnetization diagrams of some representative samples from Guanajuato, Mexico. Solid circles correspond to projections in the horizontal plane and open triangles represent projections in the vertical plane. AF demagnetization steps are in millitesla $(\mathrm{mt})$, and thermal demagnetization steps are in degrees Celsius. Scale divisions are $10^{-5} \mathrm{emu} / \mathrm{g}(d)$ or $10^{-6} \mathrm{emu} / \mathrm{g}(a-c)$. Diagrams are samples with normal $(a-b)$ or reversed $(c-d)$ polarity characteristic remanences, with section and sample number indicated for each. Characteristic remanence directions (table 3) were determined using principal components/least squares fit analyses (Kirschvink 1980). See supplementary data (figs. 711; tables 5-7 in the online edition of the Journal of Geology and also available from the Data Depository in the Journal of Geology office upon request) for additional examples of normal and reversed polarity samples and a sample with complex magnetization. 


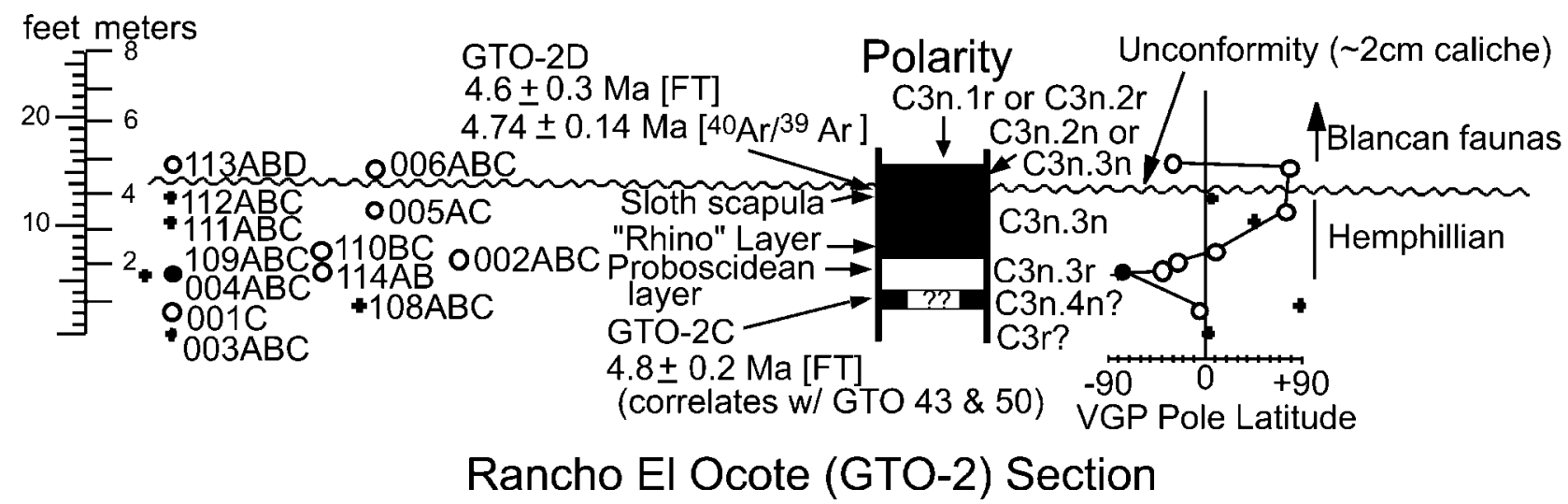

Figure 3. Rancho El Ocote paleomagnetic stratigraphy section (5.2-4.3 Ma; El Ocote GTO-2). Stratigraphic thickness, location of sample sites (numbers) with symbols reflecting classes identified in table 3 and supplementary data (figs. 7-11; tables 5-7 in the online edition of the Journal of Geology and also available from the Data Depository in the Journal of Geology office upon request; solid circle = Class I; open circle = Class II; cross = other classes), relevant biostratigraphic or radiosisotopic constraints, inferred magnetic polarity stratigraphy and correlation to global magnetic polarity timescale, and virtual geomagnetic pole latitudes for each site.

1953) to get a site mean direction and assign them to a reliability class.

The 24 Class I-III sites with specimen means having $\alpha_{95}<15^{\circ}$ and $k>30^{\circ}$ (minimum acceptable within-site dispersion for determining paleopoles; Butler 1992) were then averaged for a composite Guanajuato site mean (and paleopole latitude/longitude for the area; table 3). These data pass the reversal test of magnetic stability, using traditional methods (Watson 1956a; see Butler 1992), and the more stringent positive reversals test (scaled to number of observations; McFadden and McElhinny 1990), indicating stability for the remanence carriers of these paleomagnetic vectors. The positive reversal test for Guanajuato data can further be classified as "indeterminate" $\left(\gamma_{c}>20^{\circ}\right)$ for Class I sites (small sample size and a single normal polarity site make it difficult to reject the null) and " $\mathrm{C}$ " $\left(10^{\circ} \leq \gamma_{\mathrm{c}} \leq 20^{\circ}\right)$ for Class I + II and Class I + II + III sites. The Guanajuato section VGP position is lat $84.6^{\circ} \mathrm{N}$ long $88.2^{\circ} \mathrm{E}$ (table 3 ), consistent with Late Miocene North American paleopole estimates (Van der Voo 1993; McElhinny and McFadden 2000). In combination with new dates and ash fingerprinting, the sampling regime, remanence characteristics, and paleomagnetic methods applied thus appear to be sufficient to identify the polarity intervals preserved in the Guanajuato sequences and to correlate them to the GMPTS, although additional samples always could refine or enhance the correlations.

\section{Correlation of Individual Guanajuato Paleomagnetic Sections}

Rancho El Ocote Section. The Rancho El Ocote section (GTO-2; Carranza-Castañeda and Miller 1996) spans $\sim 6.5 \mathrm{~m}$. The samples $(n=38,13$ sites) generally gave poor paleomagnetic results, with only one highly reliable Class I site (low MAD, high $k$, and low $\alpha_{95}$; GUA-109). Five sites were not included in the magnetostratigraphy because of high MAD values (GUA-108, -111, -112) or $\alpha_{95}>90^{\circ}$ (GUA-003, -004). Several relatively well-defined normal and reversed polarity intervals are present, especially in the middle of the sequence. This suggests that the section preserves a reliable remanence signal, even with the high variability in some individual sites (fig. 3).

Hemphillian fossils occur through the middle of the Rancho El Ocote section, bracketed by two radioisotopic dates providing critical tie points for correlation of this relatively low-quality magnetostratigraphy (fig. 3). Blancan fossils occur in this section, above the highest paleomagnetic sample. The lower dated horizon (GTO-2C, GUA-108, [FT] $4.8 \pm 0.2 \mathrm{Ma}$ ) provides a lower bound for the end of the Hemphillian ( $\leq 4.8 \mathrm{Ma}$ ). The two dates from the upper horizon (GTO-2D, above GUA-112 [FT], $4.6 \pm 0.3 \mathrm{Ma}$, and [Ar/Ar], $4.74 \pm 0.14 \mathrm{Ma}$ ), a volcanic sandstone with euhedral crystals, provide a maximum age for this layer and fall within a normal polarity zone. Their congruence and very high precision indicate that the uppermost normal po- 


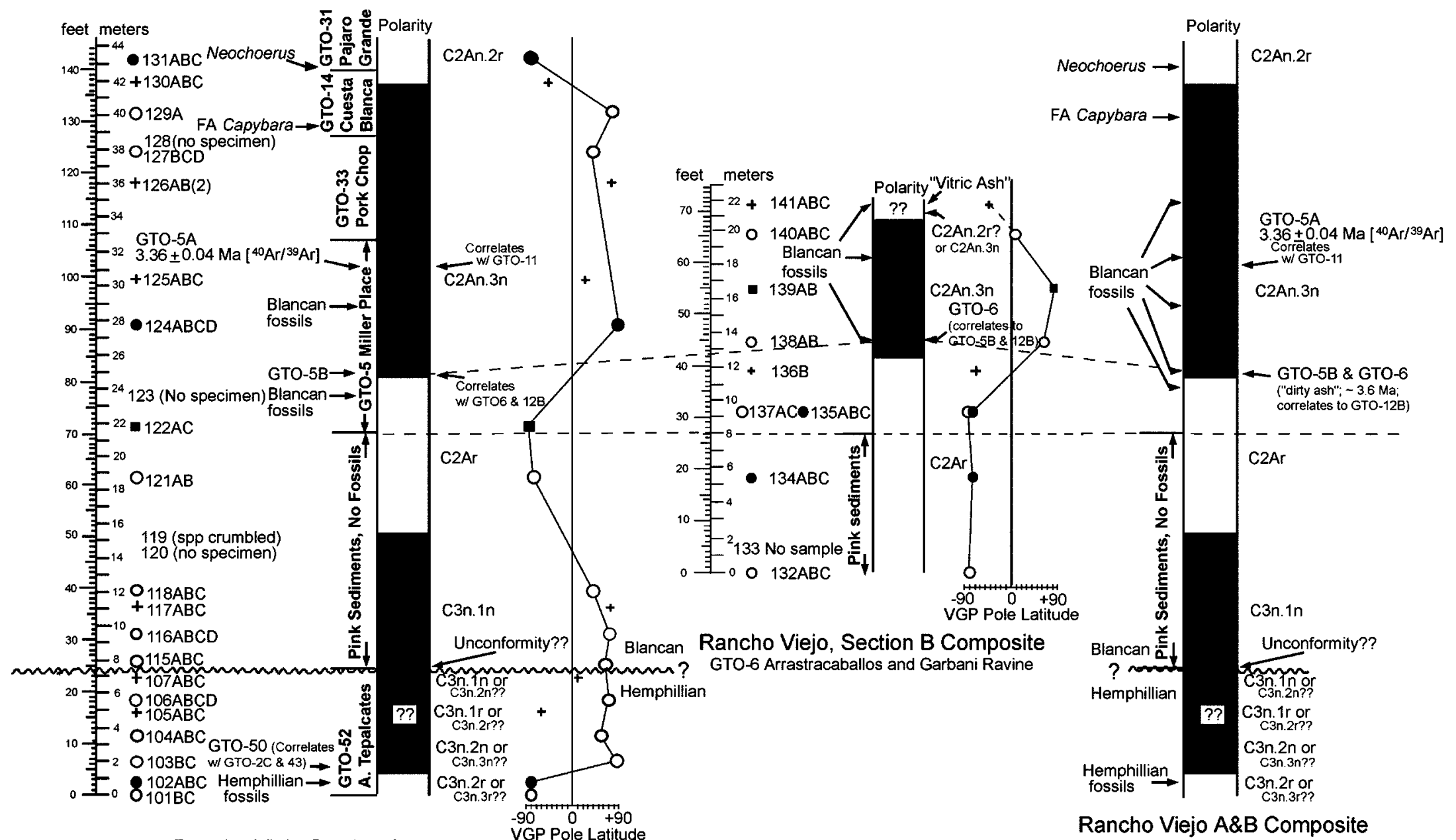

Rancho Viejo Section A

Figure 4. Rancho Viejo composite paleomagnetic stratigraphy section (sections A and B combined; for details, see supplementary data [figs. 7-11; tables 5-7 in the online edition of the Journal of Geology and also available from the Data Depository in the Journal of Geology office upon request]). Layout is the same as for figure 3 , with the addition of an inferred composite magnetostratigraphy column. 
larity zone cannot be younger than Chron C3n.3n or C3n.2n (timescale of Berggren et al. [1995]). The top of the section therefore extended through C3n.2r or C3n.1r and began by Chron C3n.3r or C3r (about 4.3-5.5 Ma); Hemphillian fossils occur at least as young as $\sim 4.7-4.8 \mathrm{Ma}$, and Blancan fossils postdate $\sim 4.7 \mathrm{Ma}$ and occur in Chron C3n. $2 \mathrm{r}$ (or C3n.1r) or younger. Thus, the Hemphillian/ Blancan boundary would lie at or younger than $\sim 4.7$ $\mathrm{Ma}$ and Chron C3n.3n. The uppermost normal polarity interval may be thinner than expected (if it is correlated to Chron C $3 \mathrm{n} .2 \mathrm{n}$ ) because of a short hiatus associated with a possible unconformity in this section. The polarity zones at the base of the section are questionably correlated to Chrons C3n.4n and C3r. If one accepts the extremely narrow range of time suggested by the means of the dates in this section and assumes that the possible unconformity did not remove any polarity zone, a modified correlation would imply that the section is even shorter (possibly only a few hundred thousand years long), spanning a single normal zone (probably correlated to C3n.3n), bracketed by a short upper reversed interval (C3n.2r) and a longer "noisy" reversed zone (C3n.3r or C3n.3r-C3r) in the lower half of the section. Alternative correlations that would be concordant with the results of Lindsay et al. (2002) would be inconsistent with the high precision dates (constraining Hemphillian fossils to be younger than $\sim 4.7-4.8 \mathrm{Ma}$ and the boundary in this section to be $<4.7-4.8 \mathrm{Ma}$ rather than at least 4.9-5.0 Ma as in Nevada) and would create conflicts between the ash correlations of Hemphillian horizons in the Rancho El OcoteRancho Viejo-La Pantera sections. The Rancho El Ocote section thus appears to begin near the Miocene/Pliocene epoch boundary and may span about half (or less) of the lower Pliocene.

Rancho Viejo Composite Sequence. This sequence spans $>40 \mathrm{~m}$ ( $140 \mathrm{ft}$; $n=80,30$ sites). The paleomagnetic samples were collected from a composite section of two almost completely overlapping local sections; these diverge from their shared basal section (fig. 4, GTO-52, 0-7 $\mathrm{m}$ in section A, Arroyo Tepalcates, sites GUA-101-107) to be separated laterally by about $2.5 \mathrm{~km}$ at their local tops. The remainder of section A (fig. 4) includes a sequential series of sites noted to the left of the section A polarity column in figure 4 (8-44 m, GUA-115-131; GTO-39, Pecos site, at level of GUA-124, is included within GTO-5, Miller Place). Section B includes two subsections (GTO-6, Arrastracaballos; GTO-11, Garbani Ravine) that overlap at their bases ("pink sediments," used as a lithostratigraphic marker unit to correlate sections A and B; fig. 4,
$22 \mathrm{~m}$ thick; sites GUA-132-141). Seven sites with extremely reliable paleomagnetic results (Class I) were included in composite Guanajuato averaging (table 3). Four additional high-reliability (Class II) sites aid in constructing the magnetostratigraphy, complemented by 16 Class III-IV sites; there are six sites of low reliability (Class $V$; five with specimens with high MAD, one with low $R /$ very large $\alpha_{95}$. In addition, the majority of polarity intervals in this sequence are defined by two or more sites. The high reliability of most of the magnetic samples, multiple sites defining most polarity intervals, long magnetostratigraphy, some biostratigraphic controls, and concordant high-resolution radioisotopic dates from the upper part of the section permit reliable correlation of the mid-upper part of the Rancho Viejo composite magnetostratigraphy (figs. 4, 6).

The lowest definitively Blancan fauna lie at GUA-123 in section A (fig. 4) and GUA-138 in section B (fig. 4), while the highest clearly Hemphillian fauna occur near the base (GUA-102) of the Arroyo Tepelcates section; the intervening interval is unfossiliferous (including the 13-m-thick pink sediments lacking fossils in sections A and B). This restricts the Hemphillian/Blancan NALMA boundary to lie within the lower half of section $\mathrm{A}$ and below GUA-138 in section B.

The best tie point for correlating the magnetic polarity intervals in the Rancho Viejo section is the GTO-5A ash bed horizon within Blancan strata, which has been precisely dated at $3.36 \pm 0.04 \mathrm{Ma}$ (new Ar/Ar date; preliminarily reported as $3.32 \pm$ $0.02 \mathrm{Ma}$ in Kowallis et al. 1998). The date suggests correlation of the long normal polarity interval in the upper half of the Rancho Viejo composite section to Chron C2An.3n (spanning 3.33-3.58 Ma). This indicates that the underlying long reversed interval in both sections A and B would correlate to Chron C2Ar (the longest chron of either polarity in the Pliocene), in turn suggesting that the underlying normal interval in section A (GUA-115118) represents Chron C3n.1n.

Sites below GUA-115 in section A are more difficult to correlate to the GMPTS. Applying different interpretations of the ambiguous "reversed" site at GUA-105 and assumptions regarding the presence of unconformities, and accepting the radioisotopically constrained correlation for the upper (Blancan) part of the sequence, several possible interpretations for the lower part seem most reasonable (fig. 6). First, given the position of the Hemphillian/Blancan boundary relative to the GMPTS in previous studies, the presence of definitively Hemphillian fossils at GUA-102 indicates 


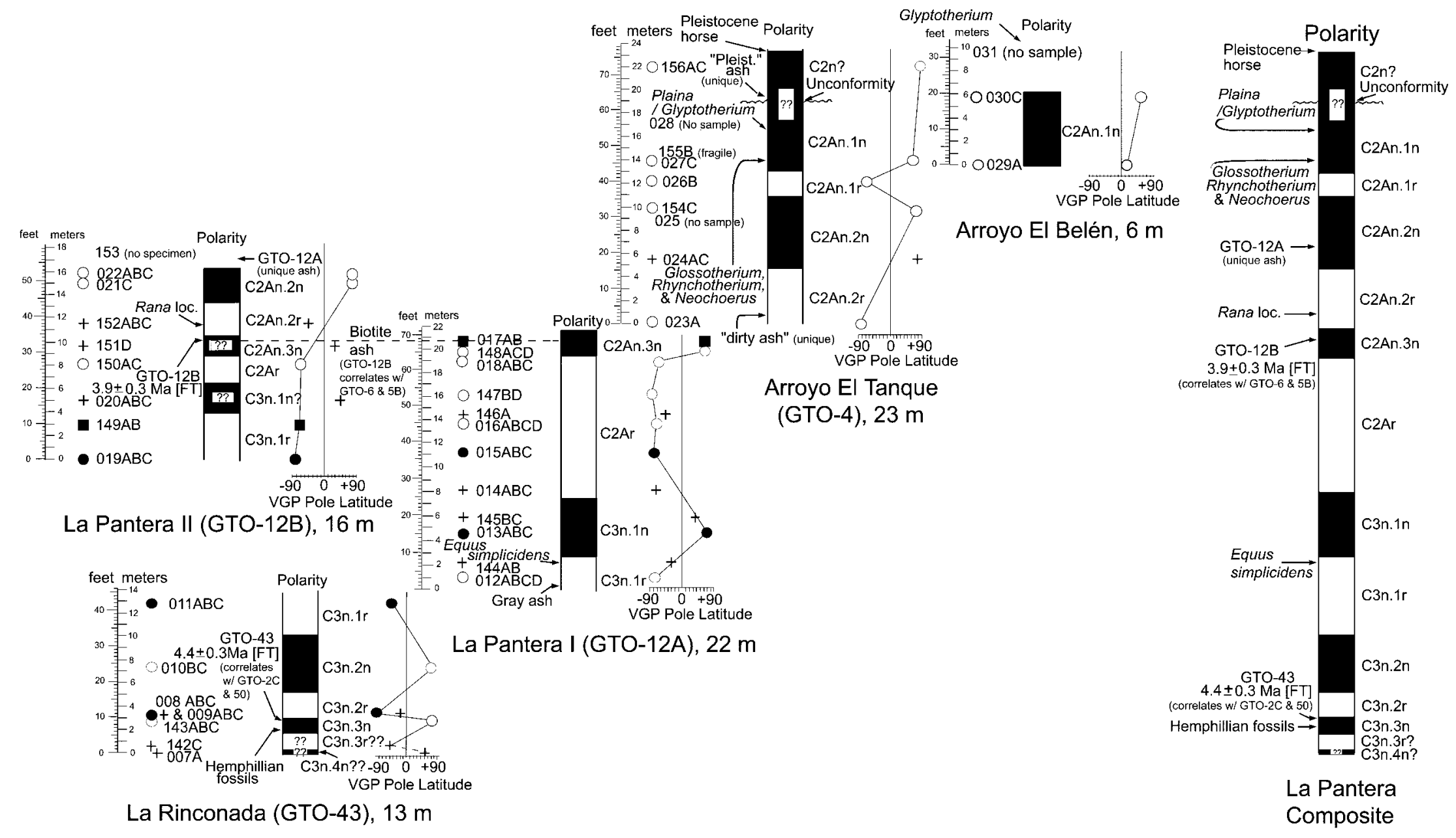

Figure 5. La Pantera composite paleomagnetic stratigraphy section (La Pantera I and II, La Rinconada, Arroyo El Tanque, Arroyo Belén). Layout is the same as for figures 3 and 4 . 
that the lowest reversed zone cannot be younger than Chron C3n.2r or C3n.3r. Correlation of the base of the sequence to Chron C3n.2r would place Hemphillian fossils above the boundary inferred by Lindsay et al. (2002) and would yield a correlation of the interval between GUA-103 and -107 to either Chron C3n.2n alone (with a small hiatus between GUA-107 and -115) or C3n.2n-C3n.1n (with no hiatus). Correlation of the base of the sequence to Chron C3n.3r (the presence of Hemphillian fossils would be consistent with prior studies) would require a hiatus between GUA-107 and -115, representing either Chron C3n.1r alone or spanning C3n.1r-C3n.2r. Correlation of the lowest reversed interval to any older chron, such as C3r, is possible, but it would require invocation of a huge but cryptic unconformity (no major erosional surfaces are present). If one assumes that there is no unconformity between GUA-107 and -115, then the lower part of the sequence correlates to either $(a)$ Chron C3n.1n-C3n.1r, if the single "reversed" site is not valid (although this is unlikely because Hemphillian fossils would persist much later than documented anywhere else), or (b) C3n.1n-C3n.2r, if the "reversed" site is valid. In all of these alternative correlations, the Hemphillian/Blancan boundary is unlikely to lie much above GUA-102, and it certainly lies below GUA-115 (because the correlation above GUA-115 is reliably constrained by the multiple dates and Blancan fossils).

The composite Rancho Viejo section magnetostratigraphy thus can reliably be correlated to Chrons C3n.1n-C2An.2r (pink sediments to top of section). It probably began by Chron C3n.2r (or possibly C3n.3r) and spans at least 1.7 m.yr. ( 3.2-4.9 $\mathrm{Ma}$ ), from near the Miocene/Pliocene boundary into the early Late Pliocene. The preferred paleomagnetic correlation and the relative lengths of the polarity intervals also indicate that there may be variability in the rates of sediment accumulation within the section (e.g., the uppermost normal zone accumulated at a relatively high rate, whereas the penultimate or middle reversed zone [Chron C2Ar correlative] accumulated at a somewhat lower than expected rate). Inclusion of the lower parts (GTO52, Arroyo Tepalcates) of these sections, with their Hemphillian faunas, in the composite magnetostratigraphy provides important constraints on the age of the Hemphillian/Blancan boundary. It also gives the Rancho Viejo composite section both an older base and longer temporal span than suggested by earlier biostratigraphic correlations (e.g., Carranza-Castañeda and Miller 1996 [p. 509], 1998, 2000; Carranza-Castañeda et al. 1994, 2000).

La Pantera Composite Sequence. The La Pantera composite paleomagnetic sequence $(n=76,33$ sites [including 10 single-sample sites]) includes four main sections: (a) La Rinconada (GTO-43; 13 m; 7 sites, two Class I), (b) La Pantera I (GTO-12A; $22 \mathrm{~m} ; 12$ sites, three Class I), (c) La Pantera II (GTO12B; $16 \mathrm{~m} ; 7$ sites, one Class I), and (d) Arroyo El Tanque (GTO-4; 23 m; fig. 5). The six Class I sites were used in the composite Guanajuato mean analyses and reversals test, and 22 (Class I-IV sites) were used in construction of the primary magnetostratigraphies. The remaining sites were typically of moderate reliability, with some of lower reliability (single specimens, high MAD, etc.); these gave results consistent with the high reliability sites and provided secondary information that reinforces or refines the polarity pattern constructed. The Arroyo El Belén section, although probably correlative with the upper part of this sequence, is discussed below.

It is possible to correlate, with various degrees of precision, the individual sections from this sequence using lithostratigraphic markers (fig. 5). The La Pantera I $(22 \mathrm{~m})$ and La Pantera II $(16 \mathrm{~m})$ sections are geographically close and appear to overlap significantly in time; the La Rinconada section (13 m) lies immediately below or overlaps the lower part of these two sections. The La Rinconada ash (GTO43, at level GUA-009, fig. 5) can be correlated to petrographically similar ashes in the Rancho El Ocote (GTO-2C, level GUA-108, fig. 3) and Rancho Viejo (GTO-5D, level GUA-103, fig. 4) sections. The dated horizon in La Pantera II (GTO-12B, above GUA-151) is a distinctive biotite ash that occurs at the top of La Pantera I (at the level of GUA-017), and can be petrographically correlated to the GTO$5 \mathrm{~B}$ ash and GTO-6 vitric ash (Ranch Viejo Sections A and B, fig. 4). A "gray ash" occurs below GUA012 in the La Pantera I section, and another is at the level of GUA-010 in the La Rinconada section; neither has been ash fingerprinted, and these levels appear to have different polarities, so their correlation is uncertain.

La Pantera I appears to be entirely Blancan in age because the Blancan indicator, Equus simplicidens, occurs near the base of the section. Blancan ages for the entire span of the La Pantera II and Arroyo El Tanque sections are also supported by $(a)$ absence of Hemphillian taxa from both sections, $(b)$ presence of the extensive Blancan fauna from the Rana Locality in the middle of La Pantera II, $(c)$ numerous Blancan taxon occurrences throughout the Arroyo El Tanque section (including Glossotherium, Rhynchotherium, and the capybara Neochoerus at site GUA-027; Plaina and Glyptotherium between sites GUA-155 and -028; and a Pleistocene horse from 


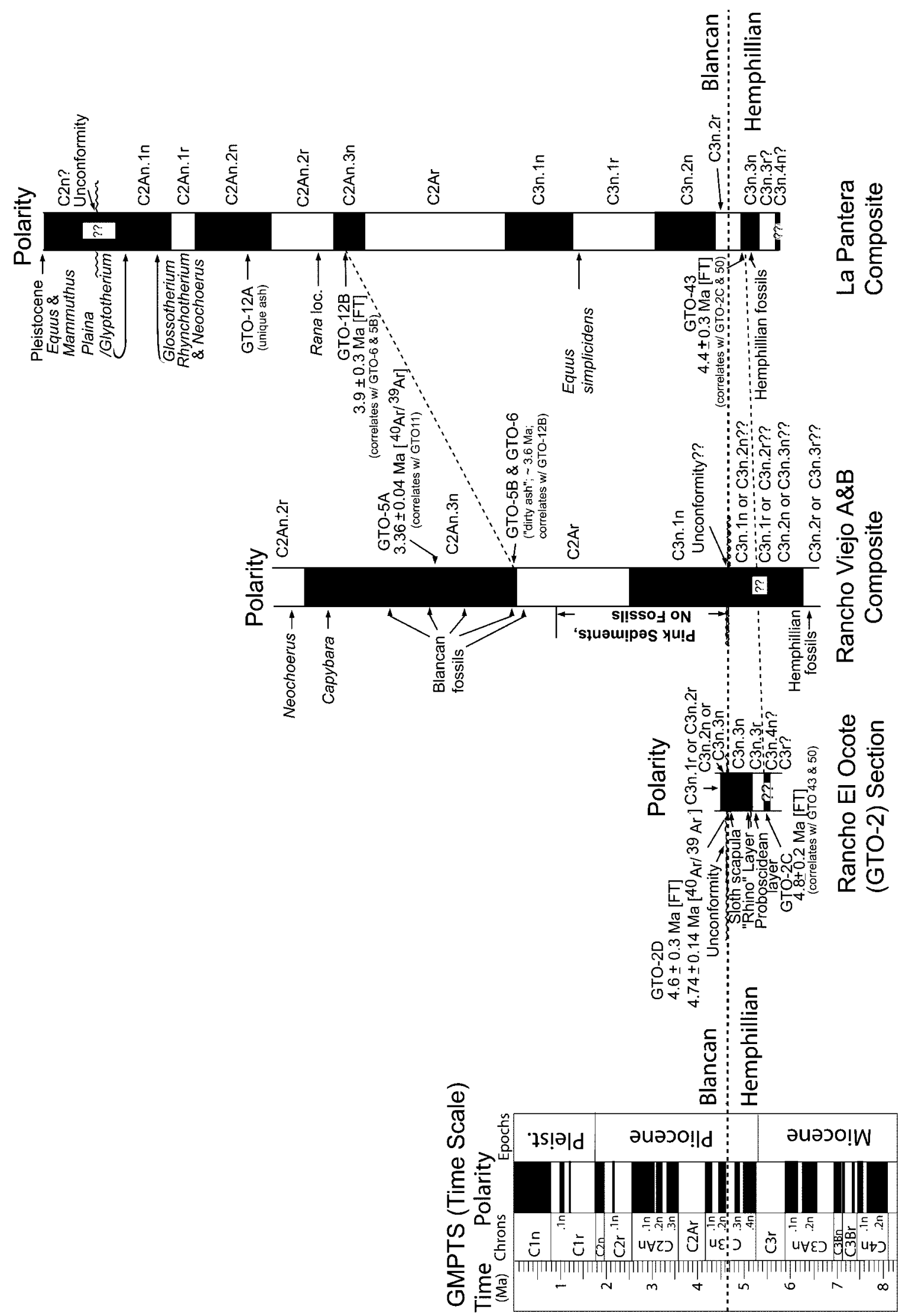


at or above site GUA-156 at the top of the section), and $(d)$ the biotite ash and magnetostratigraphic correlations of the La Pantera I and II sections. Additional independent chronologic constraints on these individual sections within the La Pantera composite include $(a)$ Blancan faunas at site GUA144 in the La Pantera I section, (b) Hemphillian faunas between sites GUA-142/143 in the La Rinconada section, and $(c)$ zircon FT mean dates of $4.4 \pm 0.3 \mathrm{Ma}$ (GTO-43; "La Rinconada ash" [fig. 1; Kowallis et al. 1998]) in the La Rinconada section and $3.9 \pm 0.3 \mathrm{Ma}$ (GTO-12B; lower biotite ash, between GUA-151/152 associated with the Blancan Rana Locality) within the La Pantera II section.

Each individual section yields a relatively short magnetostratigraphy, but lithostratigraphic correlations, ash horizons, faunas, section magnetostratigraphies, and radioisotopic dates yield a long composite section that can be unambiguously correlated to the GMPTS (figs. 5, 6). The La Rinconada section contains one to three normal and reversed polarity intervals (depending on interpretation of ambiguous and/or single sites)—we tentatively favor three zones of each polarity. The La Pantera I section has a basal reversed polarity interval followed by two well-defined normals and an intervening reversed zone. The magnetostratigraphy of La Pantera II is similar, but the two lower normal intervals are ambiguously defined. Lithostratigraphic correlation of the biotite ash indicates that the higher ambiguously defined normal in La Pantera II should correlate with the uppermost wellsupported normal interval in La Pantera I. Thus, La Pantera II appears to extend to younger horizons than does La Pantera I, and it has a sediment accumulation rate approximately one-half that in $\mathrm{La}$ Pantera I. The Arroyo El Tanque section has a basal reversed zone, followed by two long normals with an intervening short reversed; all but one of these polarity zones is defined by a single site.

Our preferred correlation of this composite sequence to the GMPTS (figs. 5, 6) spans Chron C3n.4n-C2An.1n (4.98-5.2 to 2.58-3.04 Ma). This correlation was determined using $(a)$ the minimum age for the base of the sequence provided by the La Rinconada FT date, $(b)$ an approximate age for the uppermost normal polarity interval provided by the La Pantera II FT date, $(c)$ correlation of the longest reversed interval in the sequence (middle of La Pantera I) to the longest Pliocene reversed interval (Chron C2Ar), and (d) the presence of numerous polarity zones and no obvious unconformities (indicating a long temporal span and continuous deposition). If the ambiguous intervals from low in the La Rinconada section are resolved conservatively (assuming all the basal sites are of normal polarity, as for unambiguous site GUA-143), then the base of the section may be only as old as Chron C3n.3n (4.8-4.89 Ma).

In this preferred correlation, the base of the La Pantera composite sequence is about the same age as (possibly extending slightly older than) the base of the Rancho El Ocote section, but La Pantera spans a much longer time because its top is at least 1-2 m.yr. (or more) younger.

The presence of Hemphillian fossils in Chron C3n.3n is consistent with prior placement of the Hemphillian/Blancan boundary in other North American sequences in Chron C3n.2r (Woodburne and Swisher 1995; references above) but not with its placement in Chron C3n.3r or C3n.4n (Lindsay et al. 2002). The 4.4-Ma La Rinconada GTO-43 FT date closely overlying Hemphillian fossils appears to be a little too young relative to all prior estimates of the end of the Hemphillian, by 0.2-0.6 m.yr., although it is within analytical error if the boundary at Guanajuato lies within Chron C3n.2r or the base of Chron C3n.2n (as in other sites; Woodburne and Swisher 1995). Regardless of where the Hemphillian/Blancan boundary is placed, the magnetostratigraphy indicates that the ash lies near the Chron C3n.3n/C3n.2r boundary ( 4.8 Ma, Berggren et al. 1995), also indicating that this FT date is slightly too young. Alternatively, if the mean age of the GTO-43 FT date of $4.4 \pm 0.3 \mathrm{Ma}$ (situated within the lowermost La Rinconada section) is accurate, then the magnetostratigraphy would have to be correlated differently, and the current estimates of the numerical age of the Hemphillian/ Blancan boundary or its position relative to the polarity chrons of the GMPTS, on the basis of all other North American sequences, would be incorrect

Figure 6. Correlation of Guanajuato magnetostratigraphies to the global magnetic polarity timescale (GMPTS). Columns, from left to right: standard GMPTS (Berggren et al. 1995), composite Rancho El Ocote magnetostratigraphy, composite Rancho Viejo magnetostratigraphy, and composite La Pantera magnetostratigraphy. Dotted line for correlation between sections is the inferred position of the Hemphillian/Blancan North American Land Mammal Age boundary, within Chron C3n.2r. 
Table 3. Guanajuato Paleomagnetic Mean Data

\begin{tabular}{|c|c|c|c|c|c|c|c|c|}
\hline Sequences & $n$ & Declination & Inclination & $\kappa$ & $\alpha_{95}$ & $\boldsymbol{R}$ & $\begin{array}{c}\text { VGP } \\
\text { latitude }\left({ }^{\circ} \mathrm{N}\right)\end{array}$ & $\begin{array}{c}\text { VGP } \\
\text { longitude }\left({ }^{\circ} \mathrm{E}\right)\end{array}$ \\
\hline \multicolumn{9}{|l|}{ La Pantera: } \\
\hline $\mathrm{N}$ & 3 & 356.9 & 25.95 & 15.307 & 32.6 & 2.969 & 102.0 & 82.1 \\
\hline $\mathrm{R}$ & 8 & 183.6 & -25.1 & 12.224 & 16.5 & 7.427 & 235.0 & -81.5 \\
\hline \multicolumn{9}{|l|}{ Rancho El Ocote: } \\
\hline $\mathrm{N}$ & 1 & 11.7 & 50.7 & $\ldots$ & $\ldots$ & $\ldots$ & $\ldots$ & $\ldots$ \\
\hline $\mathrm{R}$ & 1 & 178.5 & -17.9 & $\ldots$ & $\ldots$ & $\ldots$ & $\ldots$ & $\ldots$ \\
\hline \multicolumn{9}{|l|}{ Rancho Viejo: } \\
\hline $\mathrm{N}$ & 3 & 354.1 & 33.7 & 57.828 & 16.4 & 2.965 & 145.8 & 83.8 \\
\hline $\mathrm{R}$ & 8 & 175.3 & -31.5 & 30.934 & 10.1 & 7.774 & 308.0 & -84.1 \\
\hline \multicolumn{9}{|l|}{ Guanajuato composite: } \\
\hline Normally magnetized samples & 7 class I-III sites & 357.3 & 33.0 & 23.596 & 12.7 & 6.746 & 86.0 & 120.3 \\
\hline Reversely magnetized samples & 17 Class I-III sites & 179.4 & -27.8 & 18.414 & 8.5 & 16.131 & 83.7 & 84.3 \\
\hline \multirow{3}{*}{$\begin{array}{l}\text { Guanajuato composite VGP } \\
\text { position } \\
\text { North American Late Miocene } \\
\text { paleopole estimates }\end{array}$} & & & & & & & & \\
\hline & 24 Class I-III sites ${ }^{a}$ & 359.1 & 29.3 & 20.597 & 6.7 & 22.883 & 84.6 & 88.2 \\
\hline & (Interpolated from Eocene results) & $\begin{array}{l}\ldots \\
\ldots\end{array}$ & $\begin{array}{l}\cdots \\
\cdots\end{array}$ & $\begin{array}{l}\cdots \\
\cdots\end{array}$ & $\begin{array}{l}4^{\mathrm{b}} \\
\approx 3.7^{\mathrm{c}}\end{array}$ & $\begin{array}{l}\cdots \\
\cdots\end{array}$ & $\begin{array}{l}87.4^{\mathrm{b}} \\
88.8^{\mathrm{c}}\end{array}$ & $\begin{array}{l}177^{\mathrm{b}} \\
177^{\mathrm{c}}\end{array}$ \\
\hline
\end{tabular}

Note. For site data, see supplementary data (figs. 7-11; tables 5-7 in the online edition of the Journal of Geology and also available from the Data Depository in the Journal of Geology office upon request). $\mathrm{N}=$ normal polarity sites; $\mathrm{R}=$ reversed polarity sites; $n=$ number of site means averaged; $\kappa=$ Fisher precision parameter $\alpha_{95}=$ angular radius of the cone of confidence $\left(\alpha\right.$, about the observed mean); $\boldsymbol{R}=$ resultant vector, giving unit values to each " $\boldsymbol{n}^{\prime \prime}$ vector being averaged; VGP $=$ virtual geomagnetic pole.

a Combined, using antipode of individual reversed directions.

${ }^{\mathrm{a}}$ Combined, using antipode of
${ }^{\mathrm{b}}$ Van der Voo 1993, table 5.1.

${ }^{\mathrm{c}}$ McElhinny and McFadden 2000, table 6.5. 
(i.e., would be even younger, contra both Woodburne and Swisher [1995] and the even older placement of Lindsay et al. [2002]).

The La Pantera II FT date of $3.9 \pm 0.3 \mathrm{Ma}$ (GTO$12 \mathrm{~B}$ ) is associated with an ambiguously defined normal polarity interval, although this same horizon represents an unambiguous normal zone at the top of the La Pantera I section. Our preferred correlation ties this to Chron C2An.3n (3.33-3.58 Ma [Berggren et al. 1995], overlapping the younger extreme of the error bars on the FT date). The error bars could permit an alternative correlation of the normals in both La Pantera I and II to the next older normal polarity Chron, C3n.1n (4.18-4.29 Ma; shifting the entire La Pantera composite section one polarity chron older so the sequence would span Chrons C3An.1n-C2n.2n, or 5.89-6.14 to 3.11-3.22 Ma). This alternative correlation, although it could make the position of the Hemphillian/Blancan boundary more consistent with the Nevada results (Lindsay et al. 2002), would be inconsistent with the results from the other Guanajuato sequences, would imply extreme fluctuations in sediment accumulations throughout the La Pantera sequence and would make the upper date (GTO-12B) too young (by $\sim 0.3 \mathrm{Ma}$ ) and the lower date (GTO-43) much younger (by 0.6-0.8 m.yr., two to three times greater than the error associated with the date) than indicated by the GMPTS age of the chrons with which they are associated. An alternative correlation for La Pantera II alone, on the basis of the age of GTO-12B (mean within Chron $\mathrm{C} 2 \mathrm{Ar}$ ) and rejection of one or both of the ambiguous normal intervals, has the section ending in Chron C2An.3n (and beginning sometime between Chron C3n.1r and C2Ar), although this would contradict the ash fingerprint correlation with La Pantera I.

If our preferred correlation is correct and there are no major hiatuses in the upper part of the section, then the top of the La Pantera composite sequence would be Late Pliocene (about 2.58-3.04 Ma). This interpretation is well supported by the consistent polarity pattern in the three overlapping sections (La Pantera I and II, Arroyo El Tanque) and available independent age constraints. However, there is a putative "Pleistocene ash" at the top of the Arroyo El Tanque section, and common taxa in the upper part of the sequence (e.g., Glossotherium and Neochoerus) range from the late Hemphillian or Blancan (Pliocene) through Pleistocene (but note that McDonald [1995] restricts Glossotherium to the Blancan or older, referring all Irvingtonian and younger similar forms to Paramylodon). Regardless of the preferred correlation of the paleomagnetic data, there are too few polarity intervals for the La Pantera composite sequence to continuously span all of the Blancan through Pleistocene, suggesting that $(a)$ the sampling was too coarse to pick up all of the relevant polarity zones, (b) the uppermost ash is not Pleistocene, or $(c)$ there are one (or more) significant unconformities in the sequence. The latter explanation appears to be the most likely, on the basis of paleochannels in the uppermost part of the sequence below the "Pleistocene ash." If a major unconformity indeed is present at the top of the sequence, part of the highest normal may correlate to a Pleistocene chron(s).

Arroyo Belén Section. This relatively long section (GTO-47, partial Glyptothere section; $6 \mathrm{~m}$ [12$\mathrm{m}$ stratigraphic section], two sites; fig. 5) was sparsely sampled, with the two paleomagnetic sites occurring in the lowest $6 \mathrm{~m}$ of the section. Only one individual sample could be used from each site; these both gave reliable results (with $\mathrm{MAD}<10^{\circ}$ ), but the single resultant polarity interval obviously must be interpreted with great caution. Biostratigraphic data suggest, however, that the Arroyo Belén section likely is equivalent to the upper part of the Arroyo El Tanque section (and composite La Pantera sequence). The upper of the two sites (GUA-030, $6 \mathrm{~m}$ ) occurs within a horizon bearing a proboscidean (Rhynchotherium) and a partial Glyptotherium skeleton as well as the late Hemphillian-Blancan sloth Glossotherium lie higher $(12 \mathrm{~m})$ in the section. On the basis of these occurrences the Arroyo Belén section appears to begin by the early late Blancan, and the long normal interval 10 $7 \mathrm{~m}, 0-25 \mathrm{ft}$ ) could be equivalent to any of the five normal chrons spanning the pre-Pleistocene late Blancan (Chrons C2-C2A; 1.8-3.6 Ma). We tentatively correlate the normal zone of this section to Chron C2An.1n (2.6-3.04 Ma), on the basis of the presence of several South American interchange taxa and an approximate correlation of the Arroyo Belén Glyptotherium level (just above GUA-031) to the Arroyo El Tanque Plaina level ( 2 $\mathrm{m}$ above GUA-155).

\section{Correlation of the Individual and Composite Guanajuato Sequences}

Our preferred correlations of the individual Guanajuato magnetic polarity sections to the MiocenePleistocene GMPTS (Berggren et al. 1995) are shown in the composite correlation diagram of figure 6, and their chronologic implications are summarized in table 4 . The three main sequences can be correlated to each other using direct lithostratigraphic ties, ash fingerprinting, and correlations suggested by the radioisotopic dates and magne- 
Table 4. Summary of Chronologic Information Implicit in Preferred Magnetostratigraphic Correlations of Guanajuato Sections

\begin{tabular}{|c|c|c|}
\hline Section & Chrons/ages represented & Temporal span \\
\hline Rancho El Ocote: & $\begin{array}{l}\text { Chrons C3n.2r-C3r (possibly extending to } \\
\text { Chron C3n.1r); } \sim 4.4-5.5 \mathrm{Ma}\end{array}$ & $\begin{array}{l}\text { Latest Miocene to Early Pliocene; } \\
\sim 1.1 \text { m.yr. total temporal span }\end{array}$ \\
\hline Rancho Viejo & $\begin{array}{l}\text { Chrons C2An.2r-C3n.3r; Early Pliocene, } \\
\text { 3.25-4.95 Ma }\end{array}$ & 1.7 m.yr. \\
\hline $\begin{array}{l}\text { La Pantera composite: } \\
\text { La Pantera I and II/ }\end{array}$ & Chrons C2An.1n-C3n.4n; 2.8-5.1 Ma & 2.3 m.yr. \\
\hline Arroyo El Tanque & Chron C2An.1n-C3n.1r; 2.8-4.4 Ma & 1.6 m.yr. \\
\hline La Rinconada & Chron C3n.1r-C3n.4n; 4.4-5.1 Ma & $\begin{array}{l}.7 \text { m.yr. (only Hemphillian faunas } \\
\text { are currently known from this } \\
\text { section) }\end{array}$ \\
\hline Arroyo Belén & (?) Chron C2An.1n; 2.58-3.04 Ma & Maximum duration of .4 m.yr. \\
\hline
\end{tabular}

Note. Temporal spans were estimated using approximate midpoint ages of chrons. For Arroyo Belén, the single polarity zone could be any normal chron between Chrons $\mathrm{C} 2$ and $\mathrm{C} 2 \mathrm{~A}$, as young as $1.8 \mathrm{Ma}$ or as old as $3.6 \mathrm{Ma}$; biostratigraphy favors the preferred correlation.

tostratigraphy. The biostratigraphic data were used to infer the most likely position of the Hemphillian/Blancan boundary within each of the Guanajuato sections; this boundary was kept independent of the magnetostratigraphic correlations but was used as a "datum" for visually aligning the individual sections. Most of the Guanajuato sequences overlap extensively in time, but the relative thicknesses of equivalent correlated polarity zones suggest large differences in sediment accumulation rates between sequences.

The Rancho El Ocote magnetostratigraphic section is of relatively low quality and must be interpreted with caution, although two horizons yielded high-precision radioisotopic dates, permitting more definitive correlation. The long Rancho Viejo composite sequence (fig. 4) was the highest quality magnetostratigraphic record sampled; this, together with its biostratigraphic controls, makes correlation of this sequence to Chrons C3n.3r-C2An.2r reasonably secure. The La Pantera composite sequence (fig. 5) produced moderately high-quality magnetic results, and it represents the longest temporal span of the Guanajuato sections, Chron C3n.4n-C2An.1n (or possibly even C2n), or earliest to Late Pliocene. Correlation of this long sequence to the GMPTS benefited from extensive biostratigraphic data, radioisotopic dates near the top $(3.9 \pm 0.3 \mathrm{Ma})$ and bottom $(4.4 \pm 0.3 \mathrm{Ma})$ of the sequence, and good lithostratigraphic correlations among, and temporal overlap of, the geographically proximate individual sections (including repeated polarity patterns in three independent samplings of the upper part). The single normal polarity interval in the Arroyo Belén section is tentatively correlated to Chron C2An.1n (2.58-3.04 Ma) on the basis of biostratigraphy and correlation to the Arroyo El Tanque section.
The series of sections sampled are Late Pliocene to possibly latest Miocene in age, spanning about 2.7 m.yr., from Chrons C3n.4n or C3r (5.1 or 5.5 $\mathrm{Ma})$ to $\mathrm{C} 2 \mathrm{An} . \ln (2.8 \mathrm{Ma})$, on the basis of available magnetostratigraphic and radioisotopic data. This sequence may span an even longer time interval if unconformities are present (e.g., if Pleistocene horizons occur in the uppermost part of the Arroyo El Tanque section or if the fauna and associated magnetozones near the base of the Rancho Viejo section are older than late Hemphillian) or if biostratigraphically older strata (e.g., Late Miocene, late Hemphillian, up to $6.5 \mathrm{Ma}$ in age) were not yet sampled paleomagnetically.

Together, the radioisotopic, paleomagnetic, and biostratigraphic (see below) data much more precisely constrain the geochronology of both the local sections and the composite Guanajuato upper Miocene-Pliocene stratigraphic sequence, making the Guanajuato sequence one of the most complete and precisely age-calibrated sequences in North America spanning the Hemphillian/Blancan NALMA boundary interval. The Hemphillian/Blancan NALMA boundary almost certainly is present within all three main Guanajuato area paleomagnetic sequences (Rancho El Ocote, Rancho Viejo, La Pantera), and it appears to occur very early within the Pliocene. Alone, concordant FT and ${ }^{40} \mathrm{Ar} /{ }^{39} \mathrm{Ar}$ dates associated with Blancan and Hemphillian faunas (and thus bracketing the boundary) constrain the boundary age to be $\sim 4.7-4.8 \mathrm{Ma}$. These radioisotopic age constraints further permit a reliable correlation of our new Guanajuato sequence magnetostratigraphy, yielding a series of broader chronologic and biogeographic implications. Of particular importance is the long and unambiguously correlated La Pantera composite (in which Hemphillian fossils occur in strata as young 
as Chron C3n.3n) and the Rancho El Ocote section (in which the boundary lies between or above horizons precisely dated at 4.7 and $4.8 \mathrm{Ma}$ ). Within the framework of our preferred correlation and new radioisotopic dates, the oldest Blancan fossils at Guanajuato occur in the La Pantera composite, within Chron C3n.1r (4.3-4.5 Ma) or in Rancho El Ocote horizons that are $\leq 4.7 \mathrm{Ma}$ (on the basis of underlying dates) and just above Chron C3n.2r or C3n.1r (4.6-4.8 Ma or 4.3-4.5 Ma), while the youngest Hemphillian fossils are $\geq 4.4 \mathrm{Ma}$ (La Pantera) or 4.7-4.8 Ma (Rancho El Ocote) and occur within Chron C3n.3n (4.8-4.9 Ma). These results are consistent with some recent prior age estimates (e.g., 4.8 Ma; Repenning 1987; Kowallis et al. 1998) and correlation of the boundary to lie within Chron C3n.2r (e.g., Lindsay et al. 1975, 1984; Lundelius et al. 1987; Woodburne and Swisher [1995; 4.9 Ma]). They do, however, suggest a slightly older numerical age than estimated in some earlier articles (e.g., $~ 4.0-4.4 \mathrm{Ma}$; Lundelius et al. 1987) and a slightly younger chron correlation and numerical estimate than that of Lindsay et al. (2002; 4.9-5.0 $\mathrm{Ma}$, in Chron C3n.3r or latest C3n.4n). Accepting the likely reliability of both the Guanajuato and Nevada correlations, there are at least two potential explanations for the small discrepancies between the results presented here and those of Lindsay et al. (2002). First, the Hemphillian/Blancan boundary in Nevada is recognized by a single taxon datum, which can be demonstrably time-transgressive (Flynn et al. 1984) so that the placement of the boundary in Nevada and Guanajuato might differ accordingly. Second, if the boundary is determined by locations of first appearances of immigrant taxa from Asia, it might be older farther north, whether single or multiple taxa are used. Similarly, if this boundary were to be alternatively defined (or recognized) by the first appearance of some South American immigrants, our data show that it would be placed earlier in Guanajuato than at higher latitudes. While large-scale heterochrony has not yet been demonstrated for NALMA assemblages (see Flynn et al. 1984), high-resolution integrative geochronologic studies that could test synchrony have been rare. Our results suggest potential asynchrony of boundaries that are recognized by one or more immigrant taxa, especially across wide geographic spans or province boundaries, and that future tests can be provided by additional high-resolution studies comparing province-boundary regions with more central areas.

\section{Implications for the GABI}

It has long been known that a major faunal interchange between North and South America occurred during the Late Pliocene, presumably in response to dramatic paleogeographic and climatic changes associated with the complete formation of the Isthmus of Panama (e.g., summaries in Patterson and Pascual 1972; Simpson 1980; Stehli and Webb 1985; Marshall 1988; Jackson et al. 1996). However, determining the precise timing of this GABI event and the temporal and spatial pattern of faunal changes across this interval has been hindered by the paucity of data available from critical biogeographic areas and the very few reasonably continuous fossil-bearing sections spanning this interval (e.g., Flynn and Swisher 1995; Woodburne and Swisher 1995; Lindsay et al. 2002). Within North America, the GABI generally has been considered to be a late Blancan event. Woodburne and Swisher (1995, p. 352) stated that "Bl2 [Blancan 2, late Blancan] and the Great American Interchange are taken as coeval at about $2.7 \mathrm{Ma},{ }^{\prime \prime}$ and the beginning of the late Blancan has been placed at the immigrational first appearances of Neotropical taxa (including Glossotherium, Glyptotherium, Kraglievichia [=Pampatherium], Dasypus, Neochoerus, and Erethizon; Lundelius et al. 1987; Woodburne and Swisher 1995). Although it may be crucial to understanding the GABI, the slightly older Hemphillian/Blancan NALMA boundary interval has been poorly known throughout North America (see "Introduction"). Thus, the presence of a relatively complete, fossil-rich section spanning earlier intervals $(\sim 2.8-5.5 \mathrm{Ma})$ at Guanajuato, situated within the previously poorly sampled middle American region and representing the southernmost extensive Late Tertiary North American sequences, provides new and better constraints on the timing and pattern of biotic changes that occurred during the GABI.

Interestingly, partly because of the asymmetry in the magnitude and directions of dispersal (but also because of greater continuity and sampling), our best knowledge of the timing of the peak of the GABI had come from Patagonian South America. In those sequences, the dominant influx of North American invaders began in the Uquian SALMA. Few North American invaders are known from the preceding Chapadmalalan SALMA (3.4-4.0 Ma), although a relatively short ( 0.5-0.8 m.yr. long) but important gap occurs between the Uquian and Chapadmalalan SALMA (Flynn and Swisher 1995). The Uquian SALMA possibly began as early as $3.0 \mathrm{Ma}$ and continued until $1.5 \mathrm{Ma}$, although there are cor- 
relation and calibration problems (Flynn and Swisher 1995, p. 327), and some researchers have suggested that the Uquian SALMA did not begin until 2.5 or 2.6 Ma (e.g., Marshall et al. 1992 and MacFadden et al. 1993, respectively). The main influx of taxa into southern temperate regions of South America postdated 3.4 Ma and preceded 2.53.0 Ma, thus occurring slightly before or contemporaneously with the late Blancan events noted previously in North America (at $2.7 \mathrm{Ma}$ ).

Significantly, even with only initial biostratigraphic studies (e.g., figs. 3-6; references cited in "Introduction"), the Guanajuato strata provide extensive Hemphillian and Blancan faunas, constraining the position of the Hemphillian/Blancan boundary in lower latitudes. A wide diversity of North American taxa, in addition to the various South American immigrants, occur within the Guanajuato sections, independently constraining the position of the Hemphillian/Blancan biochronologic boundary. For example, key Hemphillian taxa in the Rancho El Ocote section include Agriotherium, Osteoborus (synonymized with Borophagus by Wang et al. [1999], but we consider the two forms to be distinct), Teleoceras, Nannippus minor, Neohipparion, Astrohippus, and Prosthennops, while Blancan horizons in several sections containing South American migrants include typical North American Paenemarmota, Spermophilus, Felis, Trigonictis, Borophagus, Rhynchotherium, Nannippus peninsulatus, Equus, and Platygonus (Carranza-Castañeda et al. 2000). When combined with the new chronologic constraints provided by the radioisotopic dating and magnetostratigraphic correlations, these biostratigraphic data document a variety of very early occurrences of South American invaders, some of which are up to $2 \mathrm{~m}$.yr. or more earlier than the previously recorded beginnings of the GABI elsewhere in North America (e.g., beginning of the late Blancan [Bl 2], 2.7-3.1 $\mathrm{Ma})$.

The earliest xenarthrans in North America, present by the early Hemphillian $\sim 9 \mathrm{Ma}$, have long been known to be sloths (i.e., Pliometanastes protistus and Thinobadistes segnis, with Megalonyx [currently known only from North America but closely related to or derived from immigrant Pliometanastes] from slightly younger deposits; Hirschfeld and Webb 1968; Hirschfeld 1981; Tedford et al. 1987; Webb 1989|. However, the Guanajuato sequence documents older occurrences for a variety of other xenarthrans, extending their age of arrival or FA by up to 1.5-2.0 m.yr. or more, including the presence of Glossotherium and Megalonyx by 4.7-4.8 Ma (late Hemphillian; Rancho El
Ocote), Plaina by 4.6-4.7 Ma (early Blancan, Rancho El Ocote), and Glyptotherium by 3.1-3.9 Ma (early Blancan, Rancho Viejo, and La Pantera). The oldest known occurrence of a caviomorph rodent (Hydrochoeridae, capybaras) within North America is now well documented by fossils within Blancan horizons of Guanajuato that are at least as old as 3.1-3.5 Ma (e.g., Neochoerus, Rancho Viejo, in Chron C2An.3n; fig. 4) or older (e.g., Neochoerus, low in Arroyo El Tanque, correlative with levels slightly above a 3.9 Ma FT date in La Pantera II; fig. 5), extending the FA of this taxon to predate prior estimates by $0.3-0.5 \mathrm{~m}$.yr. or more.

Within the Guanajuato sections (figs. 3-6), therefore, we observe that a variety of immigrant taxa all occur earlier within lower latitude Middle America than in more temperate parts of North America. These include Megalonyx, Glossotherium, and Plaina (occurring by at least 4.7-4.8 Ma, late Hemphillian), as well as slightly later-appearing immigrants (e.g., Neochoerus and Glyptotherium by the early Blancan, $\geq 3.1-3.9 \mathrm{Ma}$ ). The late Hemphillian immigrants might have arrived even earlier, given the very fragmentary early Hemphillian record from Middle America, a limitation that may be alleviated by a new and more complete Guanajuato and Jalisco biostratigraphies (Carranza-Castañeda 2004) or future discoveries in Middle America. If the youngest Hemphillian faunas are slightly older than suggested by our preferred correlations (i.e., older than $\sim 4.9-5.0 \mathrm{Ma}$ and in Chron C3n.3r or latest C3n.4n, as in Lindsay et al. 2002), then it would push these precocious occurrences of Neotropical immigrants back even further, by at least 200,000 years. Thus, three of the four Neotropical immigrant taxa (Neochoerus, Glossotherium, Glyptotherium) used by Lundelius et al. (1987) to mark the beginning of the late Blancan $(\sim 2.7 \mathrm{Ma})$ actually arrived much earlier in North America than previously recorded. The heterochronic FA of these five individual immigrant taxa also indicate, therefore, that their arrivals can no longer be used in defining the beginning of the late Blancan. Similarly, the possibility (perhaps even likelihood) of diachronous first appearances of individual immigrants (see also Flynn et al. 1984; Alroy 1998) argue for great caution when using only one or two immigrant taxa to define or recognize biochronologic or chronostratigraphic boundaries.

Together with the earliest arriving immigrants (the sloths Pliometanastes and Thinobadistes, whose FA in northern temperate latitude records have been used to mark the beginning of the Hemphillian), the Guanajuato records indicate that at least seven South American forms were already 
present by the late Hemphillian-early Blancan. This not only pushes back the beginning of major phase of GABI immigrants into North America to much earlier than previous conceptions of its commencement (late Blancan) but also to well precede the earliest documented major influx of North American migrants into South America.

The sequential series of individual taxon FA records at Guanajuato (spread over at least 1-2 m.yr., and diachronous relative to higher latitude sequences), however, suggest a much more staggered, variable arrival and dispersal of individual South American immigrants (at least three episodes at $\sim 9$, 4.7-4.8, and $>3.1-3.9 \mathrm{Ma}$ ). This is in striking contrast to the rapid "en masse" pulse of incursions previously suggested by the simultaneous FA of many taxa at the beginning of the late Blancan in temperate North American sequences. The apparently synchronized FA of many taxa at higher latitudes may be due to a short but real depositional hiatus during this crucial 5-3-Ma interval. Because there are at least a few fossiliferous sequences of about this age in the United States, it is more likely that faunal provinciality existed between the two regions, partly isolating them and delaying further migration until species adapted and migrated or climate/habitat changes reduced provinciality or altered boundaries (when additional South American taxa also appear in the United States and a major pulse of North American immigrants appear in high-latitude South America). Similar early appearance patterns in low latitudes have been suggested by Campbell et al. (2001) from South American tropical records, on the basis of intriguing but much less extensive geochronologic data $\left({ }^{40} \mathrm{Ar} /{ }^{39} \mathrm{Ar}\right.$ date of $9.01 \pm 0.28 \mathrm{Ma}$ from a level believed to postdate horizons with North American immigrant taxa but from channelized sequences $\sim 100 \mathrm{~km}$ from the faunas).

Shift of the beginning of the interchange to older ages, with a much less cohesive migration of "legions" of taxa, now better constrain the timing and pattern of the GABI. These new patterns then can be used to test potential explanations for the GABI (e.g., correlations with timing of completion of the
Isthmus of Panama, related [or at least coeval] climatic changes perhaps resulting from oceanic and atmospheric circulation changes when the isthmus was completed, various sea level fluctuations, etc.). For example, while sea level changes clearly played a role in the GABI, it does not appear to be directly associated with the particular Type 1 sea level lowstand TB3.8 suggested by Woodburne and Swisher (1995) to correlate with the GABI and immigration into North America of a variety of South American taxa (Erethizon, Neochoerus, Glossotherium, Glyptotherium). If anything, the older FA ages (around 4.7-4.8 Ma, near the Hemphillian/Blancan boundary) indicated by the Guanajuato data correlate to the smaller magnitude drop (and generally higher sea levels, overall) around TB3.5, well preceding final formation of the Isthmus of Panama and associated oceanographic and climatic changes about 3-3.5 Ma. Additional high-resolution biostratigraphic and geochronologic studies at Guanajuato and eventually of other low-latitude Nearctic and Neotropical sections, will provide data essential for better understanding of the degree of synchrony of individual taxon first-appearance datums and broader NALMA-level assemblages, as well as the patterns and processes leading to this dramatic reorganization of New World mammal faunas.

\section{A C K N O W L E D G M E N T S}

The Instituto de Geologia, Universidad Nacional Autónoma de México (UNAM), provided longstanding support for the paleontological and geological studies of Central Mexico. Our home institutions and colleagues at the Field Museum, UNAM, Brigham Young University, Berkeley Geochronology Lab, and University of Arizona also supported us in a variety of ways. We gratefully acknowledge funding of this research by the National Science Foundation (EAR 9316895, 9902898). Related aspects of this project were aided by the Earthwatch Institute, Conacyt, and National Geographic Society. Revisions were undertaken, in part, with the support of a John Simon Guggenheim Memorial Foundation Fellowship to J. J. Flynn.

\section{REFEREN C ES CITED}

Adams, A. J. 2001. Late Cenozoic sedimentation in the San Miguel de Allende basin, Guanajuato, Mexico. MS thesis, Brigham Young University, Provo, UT, 95 pp.

Albright, L. B., III. 1999. Biostratigraphy and vertebrate paleontology of the San Timoteo Badlands, southern California. Univ. Calif. Publ. Geol. Sci. 144:1-121.
Alroy, J. 1998. Diachrony of mammalian appearance events: implications for biochronology. Geology 26: 23-26.

Berggren, W. A.; Kent, D. V.; Swisher, C. C., III; and Aubry, M.-P. 1995. A revised Cenozoic geochronology and chronostratigraphy. In Berggren, W. A.; Kent, D. 
V.; Aubry, M.-P.; and Hardenbol, J., eds. Geochronology, time-scales, and global stratigraphic correlation. SEPM Spec. Publ. 54:129-212.

Butler, R. F. 1992. Paleomagnetism. Blackwell Scientific, Boston, $319 \mathrm{p}$.

Campbell, K. E., Jr.; Heizler, M.; Frailey, C. D.; RomeroPittman, L.; and Prothero, D. R. 2001. Upper Cenozoic chronostratigraphy of the southwestern Amazon Basin. Geology 29:595-598.

Carranza-Castañeda, O. 1989. Biostratigrafia de los sedimentos continentales del Terciario tardio, del area de San Miguel de Allende, Guanajuato, México. PhD dissertation, Universidad Nacional Autónoma de México, $173 \mathrm{pp}$.

1991. Faunas de vertebrados fosiles del Terciario Tardio del Centro de México. Memorias III Congr. Nac. Paleontol., Soc. Paleontol. Méx. D.F., p. 20-26.

1992. Una nueva localidad del Henfiliano tardio en la Mesa Central de México. Univ. Nac. Autón. Méx. Inst. Geol. Rev. 10:179-196.

Carranza-Castañeda, O., and Ferrusquía-Villafranca, I. 1978. Nuevas investigaciones sobre la fauna de Rancho El Ocote, Plioceno Medio de Guanajuato, México. Informe Prelim., Univ. Nac. Autón. Méx. Inst. Geol. Rev. 2:163-166.

Carranza-Castañeda, O.; Ferrusquía-Villanfranca, I.; and Miller, W. E. 1981. Roedores caviomorfos Pliocénicos de la región central de México. Anais II Congr. LatinoAm. Paleontol., Porto Alegre, Brazil II:721-729.

Carranza-Castañeda, O., and Miller, W. 1988. Roedores caviomorfos de la Mesa Central de México, Blancano Temprano (Plioceno tardío) de la fauna local Rancho Viejo, Estado de Guanajuato. Informe Prelim., Univ. Nac. Autón. Méx. Inst. Geol. Rev. 7:182-199.

Carranza-Castañeda, O., and Miller, W. E. 1980. The earliest capybara record in North America. Geol. Soc. Am. Abstr. Prog. 12:399.

1996. Hemphillian and Blancan felids from central Mexico. J. Paleontol. 70:509-518.

1998. Paleofaunas de vertebrados de las cuencas sedimentarias del Terciario Tardio de la faja volcanica transmexicana. Avances en investigación, paleontología de vertebrados. Univ. Autón. Est. Hidalgo Publ. Esp. 1:85-95.

2000. Selected late Cenozoic vertebrate localities in the states of Hidalgo and Guanajuato, Mexico. Avances en investigación. Univ. Autón. Est. Hidalgo Publ. Esp. p. 3-47.

- 2004. Late Tertiary terrestrial mammals from central Mexico and their relationship to South American immigrants. Rev. Bras. Paleontol. 7:249-261.

Carranza-Castañeda, O.; Miller, W. E.; and Kowallis, B. J. 2000. Recent discoveries of South American immigrants in faunas from Central Mexico with radiometric dates. J. Vertebr. Paleontol. 20(suppl. to 3):34A.

Carranza-Castañeda, O.; Petersen, M.; and Miller, W. E. 1994. Geology of the Northern San Miguel Allende area. Brigham Young Univ. Geol. Stud. 40:1-9.

Dalquest, W. W., and Mooser, O. 1980. Late Hemphillian mammals of the Ocote local fauna, Guanajuato, Mexico. Pearce-Sellards Ser. Tex. Mem. Mus. 32:1-25.

Ferrusquía-Villafranca, I., and Carranza-Castañeda, O. 1981. Mamíferos Sudamericanos del Cenozoico tardío de México y su significación paleontológica. Anais II Congr. Latino-Am. Paleontol., Porto Alegre, Brazil II: 697-708.

Fisher, R. A. 1953. Dispersion on a sphere. Proc. R. Soc. Lond. A 217:295-305.

Flynn, J. J.; Cipolletti, R. M.; and Novacek, M. J. 1989. Chronology of early Eocene marine and terrestrial strata, Baja California, Mexico. Geol. Soc. Am. Bull. 101:1182-1196.

Flynn, J. J.; Guerrero, J.; and Swisher, C. C., III. 1997. Geochronology of the Honda Group. In Kay, R. F.; Madden, R. H.; Cifelli, R. L.; and Flynn, J. J., eds. Vertebrate paleontology in the Neotropics: the Miocene fauna of La Venta, Colombia. Washington, DC, Smithsonian Institution, p. 44-59.

Flynn, J. J.; MacFadden, B. J.; and McKenna, M. C. 1984. Land-mammal ages, faunal heterochrony, and temporal resolution in Cenozoic terrestrial sequences. J. Geol. 92:687-705.

Flynn, J. J., and Swisher, C. C., III. 1995. Chronology of the Cenozoic South American land mammal ages. In Berggren, W. A.; Kent, D. V.; and Hardenbol, J., eds. Geochronology, time-scales, and global stratigraphic correlation. SEPM Spec. Publ. 54:317-333.

Galbraith, R. F. 1988. Graphical display of estimates having different standard errors. Technometrics 30:271281.

- 1990. The radial plot: graphical assessment of spread in ages. Nucl. Tracks Radiat. Meas. 17:207214.

Green, P. F. 1981. A new look at statistics in fission track dating. Nucl. Tracks 5:77-86.

Hirschfeld, S. E. 1981. Pliometanastes protistus (Edentata: Megalonychidae) from Knight's Ferry, California. PaleoBios 36:1-16.

Hirschfeld, S. E., and Webb, S. D. 1968. Plio-Pleistocene megalonychid sloths of North America. Bull. Fla. State Mus. 12:213-296.

Jackson, J. B. C.; Budd, A. F.; and Coates, A. G., eds. 1996. Evolution and environment in tropical America. Chicago, University of Chicago Press, 426 pp.

Kirschvink, J. L. 1980. The least-squares line and plane and the analysis of paleomagnetic data. Geophys. J. R. Astron. Soc. 62:699-718.

Kowallis, B. J.; Christiansen, E. H.; Deino, A. L.; Kunk, M. J.; and Heaman, L. M. 1995. Age of the Cenomanian-Turonian boundary in the western interior of the United States. Cretac. Res. 16:109-129.

Kowallis, B. J.; Heaton, J.; and Bringhurst, K. 1986. Fission-track dating of volcanically derived sedimentary rocks. Geology 14:19-22.

Kowallis, B. J.; Swisher, C. C.; Carranza-Castañeda, O.; Miller, W. E.; and Tingey, D. G. 1998. Preliminary radiometric dates in selected Late Tertiary vertebrate faunas from Mexico. Avances en Investigación, Pa- 
leontología de Vertebrados. Univ. Autón. Est. Hidalgo Publ. Esp. 1:103-108.

Lindsay, E.; Mou, Y.; Downs, W.; Pederson, J.; Kelly, T. S.; Henry, C.; and Trexler, J. 2002. Recognition of the Hemphillian/Blancan boundary in Nevada. J. Vertebr. Paleontol. 22:429-442.

Lindsay, E. H.; Johnson, N. M.; and Opdyke, N. D. 1975. Preliminary correlation of North American land mammal ages and geomagnetic chronology. Univ. Mich. Pap. Paleontol. 12:111-114.

Lindsay, E. H.; Opdyke, N. D.; and Johnson, N. M. 1984. Blancan-Hemphillian land mammal ages and late Cenozoic mammal dispersal events. Annu. Rev. Earth Planet. Sci. 12:445-488.

Lundelius, E. L.; Churcher, C. S.; Downs, T.; Harington, C. R.; Lindsay, E. H.; Schultz, G. E.; Semken, H. A.; Webb, S. D.; and Zakrzewski, R. J. 1987. The North American Quaternary sequence. In Woodburne, M. O., ed. Cenozoic mammals of North America, geochronology and biostratigraphy. Berkeley, University of California Press, p. 211-236.

MacFadden, B. J.; Anaya, F.; and Argollo, J. 1993. Magnetic polarity stratigraphy of Inchasi: a Pliocene mammal-bearing locality from the Bolivian Andes deposited just before the great American interchange. Earth Planet. Sci. Lett. 114:229-241.

Marshall, L. G. 1988. Land mammals and the great American interchange. Am. Sci. 76:380-388.

Marshall, L. G.; Swisher, C. C., III; Lavenu, A.; Hoffstetter, R.; and Curtis, G. H. 1992. Geochronology of the mammal-bearing late Cenozoic on the northern Altiplano, Bolivia. J. S. Am. Earth Sci. 5:1-19.

McDonald, H. G. 1995. Gravigrade xenarthrans from the early Pleistocene Leisey Shell Pit 1A, Florida. Bull. Fla. Mus. Nat. Hist. 37(part II):345-373.

McElhinny, M. W., and McFadden, P. L. 2000. Paleomagnetism: continents and oceans. San Diego, CA, Academic Press, 386 pp.

McFadden, P. L., and McElhinny, M. W. 1990. Classification of the reversal test in paleomagnetism. Geophys. J. Int. 103:725-729.

Miller, W. E., and Carranza-Castañeda, O. 1984. Late Cenozoic mammals from central Mexico. J. Vertebr. Paleontol. 4:216-236.

- 1998. Late Tertiary canids from central Mexico. J. Paleontol. 72:546-556.

- 2001. Late Cenozoic mammals from the basins of central Mexico. Boll. Soc. Palentol. Ital. 40:235-242.

Montellano-Ballesteros, M., and Carranza-Castañeda, O. 1981. Edentados Pliocénicos de la región central de México. Anais II Congr. Latino-Am. Paleontol., Porto Alegre, Brazil, II:683-691.

Opdyke, N. D.; Lindsay, E. H.; Johnson, N. M.; and Downs, T. 1977. The paleomagnetism and magnetic polarity stratigraphy of the mammal-bearing section of Anza Borrego State Park, California. Quat. Res. 7: 316-329.
Patterson, B., and Pascual, R. 1972. The fossil mammal fauna of South America. In Keast, A.; Erk, F. C.; and Glass, B., eds. Evolution, mammals, and southern continents. Albany, State University of New York Press, p. 247-309.

Repenning, C. A. 1987. Biochronology of the microtine rodents of North America. In Woodburne, M. O., ed. Cenozoic mammals of North America: geochronology and biostratigraphy. Berkeley, University of California Press, p. 236-268.

Simpson, G. G. 1980. Splendid isolation: the curious history of South American mammals. New Haven, CT, Yale University Press, 266 pp.

Stehli, F. G., and Webb, S. D., eds. 1985. The Great American Biotic Interchange. New York, Plenum, 532 p.

Tedford, R. H.; Galusha, T.; Skinner, M. F.; Taylor, B. E.; Fields, R. F.; Macdonald, J. R.; Rensberger, J. M.; Webb, S. D.; and Whistler, D. P. 1987. Faunal succession and biochronology of the Arikareean through Hemphillian interval (late Oligocene through earliest Pliocene epochs) in North America. In Woodburne, M. O., ed. Cenozoic mammals of North America: geochronology and biostratigraphy. Berkeley, University of California Press, p. 151-210.

Van der Voo, R. 1993. Paleomagnetism of the Atlantic, Tethys and Iapetus Oceans. Cambridge, Cambridge University Press, $411 \mathrm{pp}$.

Wang, X.; Tedford, R. H.; and Taylor, B. E. 1999. Phylogenetic systematics of the Borophaginae /Carnivora: Canidae). Bull. Am. Mus. Nat. Hist. 243:1-391.

Watson, G. S. 1956a. Analysis of dispersion on a sphere. R. Astron. Soc. Mon. Notices Geophys. Suppl. 7:153159.

- 1956b. A test for randomness of directions. R. Astron. Soc. Mon. Notices Geophys. Suppl. 7:160161.

Webb, S. D. 1985. Late Cenozoic mammal dispersals between the Americas. In Stehli, F. G., and Webb, S. D., eds. The great American biotic interchange. New York, Plenum, p. 357-386.

- 1989. Osteology and relationships of Thinobadistes segnis, the first mylodont sloth in North America. In Redford, K. H., and Eisenberg, J. F., eds. Advances in Neotropical mammalogy. Gainesville, FL, Sandhill Crane, p. 469-532.

1997. The great American faunal interchange. In Coates, A.G., ed. Central America. New Haven, CT, Yale University Press, p. 97-122.

Woodburne, M. O., and Swisher, C. C., III. 1995. Land mammal high-resolution geochronology, intercontinental overland dispersals, sea level, climate, and vicariance. In Berggren, W. A.; Kent, D. V.; Aubry, M.P.; and Hardenbol, J., eds. Geochronology, time-scales, and global stratigraphic correlation. SEPM Spec. Publ. 54:335-364. 